IRSH 63 (2018), pp. 4I3-448 doi:10.1017/S00208590I 8000330

(C) 2018 Internationaal Instituut voor Sociale Geschiedenis

\title{
European Reconfigurations of Transnational Activism: Solidarity and Human Rights Campaigns on Behalf of Chile during the i 970 s and ig8os
}

\author{
K IM CHRISTIAENS \\ KADOC-KU Leuven, Documentation and Research Centre \\ on Religion, Culture and Society, \\ Vlamingenstraat 39, B-3000 Leuven, Belgium \\ E-mail: kim.christiaens@kuleuven.be
}

\begin{abstract}
AвSTRACT: The overthrow of the democratically elected socialist president Salvador Allende in Chile and the human rights violations under the military junta of Augusto Pinochet spawned one of the most iconic and sustained human rights campaigns of the Cold War. Human rights scholars have argued that this movement on behalf of Chile signalled the "breakthrough" of human rights as the lingua franca of transnational activism. They have emphasized the global dimensions of these campaigns, which inspired movements mobilizing on behalf of other issues in the Third World. However, such narratives have not been corroborated by research on the campaigns as developed in Europe. Historians have so far focused on the impact of the Chilean crisis in specific countries or on particular organizations, and on the ways in which human rights activism was coloured by local and national contexts. This article aims to shift the scope of the debate by establishing relations with and crossovers from other transnational causes and campaigns, analysing the ways in which campaigns on behalf of Chile became intimately related to campaigns on intra-European issues during the I970s and I980s. It explores the so far little-studied connections between campaigns over Chile and simultaneously burgeoning movements on behalf of EastWest détente, resistance against authoritarian regimes in Southern Europe, and the plight of dissidents in Eastern Europe. It argues that campaigns on behalf of Chile were reconfigured around European themes, created bonds of solidarity within a divided Europe, and drew on analogies rather than a juxtaposition between Europe and the Third World.
\end{abstract}

$* * * * *$

In recent years, there has been growing interdisciplinary interest in the genealogy and trajectories of transnational activism during the Cold War. Next to the global anti-apartheid struggle, the worldwide impact of the authoritarian Pinochet regime in Chile (I973-1990) and the globally 
developed protest movement it spawned over the I 970 s and I 980 s became a burgeoning area of research. ${ }^{\mathrm{I}}$ The violent overthrow of the democratically elected socialist president Salvador Allende and the coming to power of the military regime of Augusto Pinochet in September 1973 focused worldwide attention on Chile. ${ }^{2}$ Support for the tens of thousands of exiles who left their country and opposition to the harshly repressive policies of the Pinochet regime became one of the most iconic causes célèbres of transnational campaigning by social movements and NGOs during the Cold War. ${ }^{3}$ This exceptional impact stemmed from various reasons, such as international sympathy with the "democratic road to socialism" pursued by the Allende government prior to its crushing, a globally developed Chilean exile movement, and the appalling repression of opponents by the Pinochet regime. ${ }^{4}$ Critically, the plight of the Andean country was projected worldwide by a transnational web of solidarity groups, NGOs, and international organizations. ${ }^{5}$ These campaigns drew on a variety of ideologies and traditions and mobilized a wide range of groups active at different levels, from local solidarity committees, trade unions, and political parties, to international NGOs. Scholars have argued, however, that these campaigns signalled and spurred the "breakthrough of human rights" as the lingua franca of transnational activism. ${ }^{6}$ Campaigns over Chile, it has been argued, marked a shift away from Marxist internationalism and revolution to liberal principles of human rights and democracy. ${ }^{7}$ The "coalitional" language of human rights offered diverse groups not only a "moralistic"

I. Olivier Compagnon and Caroline Moine (eds), Chili 1973, Un Évènement Mondial. Monde(s). Histoire, Espaces, Relations, 8 (2015); Margaret Power, "The US Movement in Solidarity with Chile in the 1970s", Latin American Perspectives, $36: 6$ (2009), pp. 46-66; Jessica Stites Mor (ed.), Human Rights and Transnational Solidarity in Cold War Latin America (Madison, WI, 2013).

2. Tanya Harmer and Alfredo Riquelme Segovia, Chile y la Guerra Fría Global (Santiago de Chile, 2014).

3. Kim Christiaens, Idesbald Goddeeris, and Magaly Rodríguez García (eds), European Solidarity with Chile, I970s-1980s (Bern [etc.], 2014).

4. Eleanor Davey, Idealism Beyond Borders: The French Revolutionary Left and the Rise of Humanitarianism, 1954-I988 (Cambridge, 2015), pp. IOI-IO3.

5. Jan Eckel, “'Under a Magnifying Glass'. The International Human Rights Campaign against Chile in the Seventies", in Stefan-Ludwig Hoffmann (ed.), Human Rights in the Twentieth Century (Cambridge, 20I I), pp. 3 I 2-342.

6. Thomas Wright, State Terrorism in Latin America: Chile, Argentina, and International Human Rights (Lanham, MD, 2007), p. 227; Samuel Moyn, "The Return of the Prodigal: The I970s as a Turning Point in Human Rights History", in Jan Eckel and Samuel Moyn (eds), The Breakthrough: Human Rights in the I970s (Philadelphia, PA, 20I4), pp. I-I4; Barbara Keys, Reclaiming American Virtue: The Human Rights Revolution of the I970s (Cambridge, MA, 20I4), p. I 48.

7. Robert Gildea, James Mark, and Niek Pas, "European Radicals and the 'Third World'", Cultural and Social History, 8:4 (201 I), pp. 449-47I. 
agreement in their opposition against Pinochet, but also contributed to a transnational and even global identity. ${ }^{8}$ Just as the Vietnam War had been "everywhere" to radical activists in the I960s, so were human rights violations in Chile universalized and connected to local struggles all over the world. ${ }^{9}$ Ever since 1973 , then, campaigns against human rights violations in Pinochet's Chile have developed into a benchmark for campaigns against dictatorships and state violence in Latin America and other regions in the Global South. ${ }^{\circ}$ Campaigns on behalf of Chile expanded over the I970s to include countries all over Latin America and beyond. Activists constructed links between the struggle against Pinochet in Chile and repression in regions as diverse and remote as Palestine, South Africa, East Timor, and Tibet. ${ }^{\mathrm{II}}$

So far, such storylines of a transnationally connected and developed movement have not been plumbed by substantial historical research. Typically, most of the historical work has remained focused on national case studies or particular organizations. Little attention has been paid to crossovers and entanglements with campaigns that developed simultaneously over other issues and countries. By and large, historians have been rather sceptical towards arguments about the global identity of human rights and solidarity movements provoked by distant issues such as Pinochet's regime, and the contribution of those movements to a "global civil society". Rather, they have exposed the limitations of such narratives by stressing the local and national dimensions of these movements, and the ways in which activism was coloured by national politics and particular contexts and concerns. ${ }^{12}$ The morality and universality of human rights, then, concealed a more instrumental, strategic, pragmatic, and local/national form of politics. ${ }^{\mathrm{I}}$ By limiting the debate to the relationship between the global and local, accounts, to date, have not painted the entire picture. One of the perspectives seldom examined is the relationship with campaigns on behalf

8. Chris Moores, "Solidarity for Chile, Transnational Activism and the Evolution of Human Rights", Moving the Social: Journal of Social History and the History of Social Movements, 57 (2017), p. I 20; Moyn, "The Return of the Prodigal".

9. George Katsiaficas, The Imagination of the New Left: A Global Analysis of I 968 (Boston, MA, 1987); Steve J. Stern, Battling for Hearts and Minds: Memory Struggles in Pinochet's Chile, 19731988 (Durham, NC, 2006), pp. xiv-xv; Tanya Harmer, Allende's Chile and the Inter-American Cold War (Chapel Hill, NC, 20I I), pp. I9I and I98; Jeremi Suri, Power and Protest: Global Revolution and the Rise of Détente (Cambridge, MA, 2003).

Io. Wright, State Terrorism in Latin America, pp. xiv-xv.

I I. Patrick William Kelly, "The 1973 Chilean Coup and the Origins of Transnational Human Rights Activism", Journal of Global History, 8:I (2013), pp. I65-1 86.

I 2. Mariana Perry, "'With a Little Help from My Friends': The Dutch Solidarity Movement and the Chilean Struggle for Democracy", European Review of Latin American and Caribbean Studies / Revista Europea de Estudios Latinoamericanos y del Caribe, Iог (2016), pp. 75-96.

I 3. Jan Eckel, "The Rebirth of Politics from the Spirit of Morality: Explaining the Human Rights Revolution of the I970s", in Eckel and Moyn, The Breakthrough, pp. 227-259; Keys, Reclaiming American Virtue. 
of transnational issues within the borders of Europe. Where authors do address connections with other movements, they refer mostly to a number of other causes in the Third World (such as the Vietnam War or solidarity with Nicaragua), ${ }^{14}$ but they seldom broaden the scope to European issues that inspired transnational activism simultaneously with the Chilean crisis in the I970s and I980s. This is a pity, for several reasons. Europe-West and East and North and South - became a primary destination for tens of thousands of Chilean exiles, and it hosted the international centres of newly recreated political parties in exile. ${ }^{\text {Is }}$ Historians of Chile's transition to democracy have established the impact of exiles' experiences in Europe and the support they received there. ${ }^{16}$ What is most striking is that the spatial and ideological reconfigurations of campaigns against Pinochet regularly focused on pan-European themes, rather than on issues in the Third World. ${ }^{17}$ For instance, upon the Pinochet coup, international observers were quick to connect the Chilean crisis with the plight of Eastern Europe. They drew similarities between the Chilean crisis and the violent crushing of the Hungarian uprising by Soviet troops in 1956 or the Warsaw Pact that truncated the Prague Spring in I968. ${ }^{18}$ In the I970s, few international issues became so conspicuously present in campaigns against Pinochet as protest against dictatorships in Portugal, Spain, and Greece, and support for the transitions to democracy that followed their collapse in the mid-I970s. In the I980s, the presumed "Pinochetization" of Poland after the declaration of martial law under General Jaruzelski was only one of many themes that brought together solidarity campaigns on behalf of Chile and the banned Polish trade union Solidarność. ${ }^{19}$

This article aims to shift attention to these intra-European issues, experiences, and identities that marked transnational campaigns on behalf of Chile. It delves into the relationship, real and imagined, with campaigns over three European issues during the I970s and I980s. First, this article

14. See, for instance, Hans Beerends and Marc Broere, De bewogen beweging, Een halve eeuw mondiale solidariteit (Amsterdam, 2004).

I 5. José del Pozo (ed.), Exiliados, emigrados y retornados. Chilenos en América y Europa, I9732004 (Santiago, 2006); Thomas C. Wright and Rudy Oñate, Flight from Chile: Voices of Exile (Albuquerque, NM, 1998), p. I23.

16. Katherine Hite, When the Romance Ended: Leaders of the Chilean Left, 1968-1998 (New York, 2000); Carlos Huneeus, "Political Mass Mobilization against Authoritarian Rule: Pinochet's Chile, 1983-88", in Adam Roberts and Timothy Garton Ash (eds), Civil Resistance and Power Politics: The Experience of Non-violent Action from Gandhi to the Present (Oxford, 2009), pp. 197-2 I 2, 206-2 10.

17. Thomas C. Wright, "Chilean Political Exile in Western Europe", in Christiaens et al., European Solidarity with Chile, pp. 47-66.

I8. Gildea et al., "European Radicals and the "Third World"”.

19. Robert Brier, "Poland's Solidarity as a Contested Symbol of the Cold War: Transatlantic Debates after the Polish Crisis", in Kiran Klaus Patel and Kenneth Weisbrode (eds), European Integration and the Atlantic Community in the I980s (New York, 2013), pp. 83-104, 100. 
looks at the ways in which campaigns on behalf of Chile became enmeshed in movements transcending the borders of the Iron Curtain, fostered relations between West and East, and became integrated into the peace movements over the I970s. The second part analyses the potent connection with campaigns against what were dubbed the "fascist" dictatorships in Southern Europe. It reveals how Chile offered a means to make sense of Europe's fascist past and to understand Southern Europe as another "Third World". Third, this article delves into the ways in which campaigns over Chile related to the emergence of dissident movements in Eastern Europe and campaigns on behalf of human rights in the Eastern bloc from the late i970s onwards. In doing so, it shows how purportedly "global" activism with an orientation towards the "Third World" became invested with and projected distinctly European themes. By uncovering these connections and their origins, this contribution develops important arguments that question normative narratives about the rise of transnational activism that have become hegemonic in historiography and public memories in Europe, notably since the end of the Cold War.

\section{BRINGING THE EAST IN: CHILE AND EAST-WEST DÉTENTE IN THE 1970 S}

Communism has not fared well in traditional storylines of human rights activism; rather, it stands as its antithesis. Opposition to Eastern European communism has indeed been considered to be one of the major stimuli for the globalization of European social movements and their turn to the "Third World" from the late I950s onwards. ${ }^{20}$ Something can be said for such a view when looking at the international reactions spawned by the crushing of Chilean democracy in September 1973. In Western Europe, the overthrow of Allende's Popular Unity seemed to stir almost as much criticism of the Soviet Union as of the US, which had opposed the Allende government as a "second Cuba" ever since it took office in 1970. ${ }^{21}$ Radical leftists were quick to blame the stalemate of détente imposed by the US and the Soviet Union for the Chilean crisis, and connected it with the repression of democracy in Eastern Europe. They linked the failure of Allende's "bourgeois reformism" to Soviet imperialism and its strategic policies in the Third World. Identifying with the radical Revolutionary Left Movement

20. Eleanor Davey, "French Adventures in Solidarity: Revolutionary Tourists and Radical Humanitarians", European Review of History, 21:4 (2014), pp. 577-595, 578-579.

21. Jonathan Haslam, The Nixon Administration and the Death of Allende's Chile: A Case of Assisted Suicide (London [etc.], 2005); Lubna Z. Qureshi, Nixon, Kissinger, and Allende: US Involvement in the 1973 Coup in Chile (Lanham, MD, 2010); Lubna Z. Qureshi and Kristian Gustafson, "Exchange: Debating US Involvement in Chile in the I970s", Journal of Cold War Studies, I4:I (2012), pp. I I4-I I7. 
(MIR) - a Chilean party that had not been part of the Popular Unity Trotskyists and other radicals saw the events in Chile as a wake-up call for the European left: the end of Chile's Popular Unity showcased the fact that an alliance between communists and Social Democrats pursued by various forces within the European left was a false strategy of revolution that served the interests of capitalism and imperialism. ${ }^{22}$ The growing attention paid by this "New Left" to human rights violations in the East - publicized in Solzhenitsyn's Gulag Archipelago only some months after the events of September 1973 - and their protest against growing currents of Ostpolitik embedded analyses of the Chilean crises in an aversion to both reformism and East-West détente. For Ernest Mandel, Chile embodied a common struggle against the anti-communist Cold War of the right - which had legitimized the coup - and the terror of Soviet communism, which discredited Marxism. ${ }^{23}$ Strikingly, it was not only the New Left, but even communist parties in Western Europe that apparently used the fall of Allende to distance themselves from Soviet models of socialism, however. It is the well-known story of the Chilean crisis that - together with indignation about the crushing of the Prague Spring in I968 - inspired the rise of "Eurocommunism". ${ }^{24}$ Especially among Italian, French, and Spanish communist parties, the failure of Allende's Popular Unity served efforts to carve out a distinct strategy towards socialism in capitalist Europe and to broaden the alliance to include Christian Democrats and other political parties to reform the state system. ${ }^{25}$ Such storylines and examples might confirm the argument that human rights campaigns staged by the Soviet camp and its allied international movements on behalf of the Chilean opposition were, much like those on behalf of other issues in the Third World, simply a failure and a matter of inefficient propaganda. ${ }^{26}$ So far, the literature has indeed buttressed the assumption that these campaigns were fatally discredited by their association with the Soviet Union: they were "all

22. Claudia Olejniczak, Die Dritte-Welt-Bewegung in Deutschland: Konzeptionelle und organisatorische Strukturmerkmale einer neuen sozialen Bewegung (Wiesbaden, 1999), p. I 26.

23. Elisa Kriza, Alexander Solzhenitsyn: Cold War Icon, Gulag Author, Russian Nationalist? A Study of His Western Reception (Stuttgart, 2014), p. I 26.

24. José Miguel Insulza, "Eurocomunismo y socialismo europeo en la situación chilena", Foro Internacional, 21:3 (1981), pp. 289-303.

25. Andrea Mulas, Allende e Berlinguer. Il Cile dell'Unidad Popular e il compromesso storico italiano (San Cesario di Lecce, 2005); Alessandro Santoni, "El Partido Comunista Italiano y el otro 'compromesso storico'. Los significados políticos de la solidaridad con Chile (1973-1977)", Historia (Santiago), 43:2 (2010), pp. 523-546.

26. Geoffrey Roberts, "Averting Armageddon: The Communist Peace Movement, 1948-1956", in Stephen A. Smith (ed.), The Oxford Handbook of the History of Communism (Oxford, 2014), pp. 322-338. 
bark and no bite" and had virtually no impact on campaigns in the West. ${ }^{27}$ This partly explains why historians have, for a long time, refused to take communist campaigns on behalf of the Chilean opposition seriously.

\section{SOCIALIST EUROPE'S SOLIDARITY WITH CHILE}

This narrative, however, becomes difficult to maintain if we see how campaigns allowed for East-West cooperation, and bridged rather than widened the distance between Western and Eastern Europe. Communist parties and peace movements were capable of positioning themselves centrally in transnational campaigns in support of the Chilean opposition throughout the I970s. Whereas the interests of the radical non-communist left rapidly dwindled - notably after the hopes for armed resistance quickly turned into an illusion - communist parties developed into a major organizational axis of campaigns against Pinochet. In many Western European countries, national Chile committees established by communist parties and peace movements connected to stage massive demonstrations and humanitarian campaigns. The large communist parties in Italy and France turned Rome and Paris into international centres of Chilean exile. ${ }^{28}$ Communist parties in the West and communist regimes in the East had been able to profile themselves as allies of the Chilean Popular Unity ever since 1970. Visits of leading Popular Unity members to Eastern Europe and reciprocal visits cultivated the idea of close economic, political, and diplomatic cooperation between the Chilean Popular Unity and communist Europe, even if historians have over recent years revealed the limits of Eastern European support for the Allende government. ${ }^{29}$ The 1973 coup blurred this contradiction, however, and allowed the Soviet Union and its allies to profile themselves as the main advocates of the Chilean victims. ${ }^{3 \circ}$ Eastern European embassies and diplomats allowed leading figures of the Chilean Popular Unity to flee the country and welcomed hundreds of exiles in Eastern Europe. ${ }^{3 \mathrm{I}}$ East Berlin and Moscow quickly became host to the international headquarters of newly created political structures of the socialist and communist party in exile. ${ }^{32}$

27. Steven L.B. Jensen, The Making of International Human Rights: The 1960s, Decolonization, and the Reconstruction of Global Values (New York, 2016).

28. Raffaele Nocera and Claudio Rolle Cruz (eds), Settantatré. Cile e Italia, destini incrociati (Naples, 2010).

29. Joaquín Fermandois, La revolución inconclusa. La izquierda chilena y el gobierno de la Unidad Popular (Santiago, 2013), pp. 427-43 I; Tobias Rupprecht, Soviet Internationalism after Stalin: Interaction and Exchange between the USSR and Latin American during the Cold War (Cambridge, 2015), p. I25.

30. Haslam, The Nixon Administration and the Death of Allende's Chile, pp. I 52-1 54.

3 I. Sebastian Koch, Zufluchtsort DDR? Chilenische Flüchtlinge und die Ausländerpolitik der SED (Paderborn, 2016). 
Historians have adopted a rather cynical view towards this engagement: Eastern European regimes used the crushing of Allende as a dramatic showcase to stress the need for a strong, party-led socialism able to fight against imperialism and capitalism, and turned solidarity with the defeated Chilean left into a tool for domestic legitimacy, just as had been the case for their campaigns over the Vietnam War in the 1960s. ${ }^{33}$ Pinochet allowed communists to distinguish good anti-fascists from bad imperialists with clean moral simplicity. Campaigns were, then, much less about bringing change in Chile than about buttressing the legitimacy of communist regimes. A key issue that matters most here, but which has so far been neglected, was that the power of solidarity with Chile became, above all, located in its potential to inspire East-West cooperation. Communist parties in the West and regimes in the East had already, since the I960s, been integrating solidarity with anti-colonial struggles in their campaigns for "peace in Europe". This, along with the quest for international cooperation with anti-colonial movements, inspired their interest in solidarity with the Vietnamese struggle against American imperialism, which, from the midI960s, became a central issue for communist peace movements that blamed the stalemate of the Cold War imposed by the US for conflict and crisis in both Europe and the Third World. ${ }^{34}$ In this respect, the potential of the Chilean cause was even more compelling. Solidarity with the Vietnamese resistance had been fraught by the competition with Mao's China and the contradiction between the armed struggle in Vietnam and "peaceful coexistence" in Europe. ${ }^{35}$ The Chilean cause, by contrast, lacked such constraints. Maoists opposed the Popular Unity of Allende, and the appalling violence against the Chilean opposition made the communist forces appear as a victim instead of an armed resistance fighter. In addition, campaigns against Pinochet could benefit from the atmosphere of crisis in Western Europe, struck by economic turmoil after the 1973 oil crisis and witnessing both growing criticism of the US and currents of East-West cooperation among a broad range of social and political movements. Already in the first

32. Inga Emmerling, Die DDR und Chile. Außenpolitik, Außenhandel und Solidarität (Berlin, 2013).

33. James Mark and Bálint Tolmár, "Hungary: Connecting the 'Responsible Roads to Socialism'? The Rise and Fall of a Culture of Chilean Solidarity, I965-89", in Christiaens et al., European Solidarity with Chile, pp. 30I-327; Michal Zourek, "Czechoslovak Policy towards Chile in the I970s and 1980s", Canadian Journal of Latin American and Caribbean Studies, 39:2 (2014), pp. 2 I I-228.

34. Gerd Horten, "Sailing in the Shadow of the Vietnam War: The GDR Government and the 'Vietnam Bonus' of the Early 1970s", German Studies Review, 36:3 (2013), pp. 557-578. Quinn Slobodian, Comrades of Color: East Germany in the Cold War World (New York, 2015).

35. James Mark et al., “'We Are with You, Vietnam'. Transnational Solidarities in Socialist Hungary, Poland and Yugoslavia”, Journal of Contemporary History, 50:3 (201 5), pp. 439-464. 
few weeks after September 1973, human rights violations in Chile appeared on the agenda of a broad assortment of international organizations that were supported by the Soviet Union and socialist countries, including the World Federation of Trade Unions, the World Federation of Democratic Youth, and the International Union of Students. As early as 22 September 1973, the World Federation of Democratic Youth and the International Union of Students staged a European Youth and Student Meeting in Paris. ${ }^{36}$ Gathering communist youth groups hailing from fifteen Western European and seven communist countries, this conference developed information campaigns, organized public campaigns such as demonstrations and petitions, collected money to aid the Chilean resistance, and called for the establishment of solidarity committees.

One of the principal fora became the World Peace Council. This Helsinki-headquartered international coordinating body of communist-led peace movements was established in the late I940s, developed a series of international campaigns against the Vietnam War and anti-colonialism over the I960s, and transitioned in the late I960s into a forum for campaigns on European security and cooperation. ${ }^{37}$ In the early i 970 , it successfully campaigned and was recognized at the level of UN institutions, for instance on the issue of anti-apartheid. ${ }^{38}$ In late September 1973, the World Peace Council and affiliated communist peace movements organized in Helsinki what was to be the first major international conference of solidarity with the Chilean resistance. ${ }^{39}$ The event was attended by leading figures of the Popular Unity in exile, delegations of communist parties and governments, national liberation movements (including the South African ANC), as well as by representatives of human rights NGOs (including Amnesty International and Christian NGOs) from all over Western Europe. ${ }^{40}$ The conference marked the start of a succession of campaigns that blended

36. European Youth and Student in Paris, 22 September 1973, Archives CEAL (Brussels); Telegram: Invitation to the Paris Meeting of the World Federation of Democratic Youth on 22 September 1973, s.d., Archives ABVV, Amsab-ISG (Ghent), no. 706.

37. Günter Wernicke, "The World Peace Council and the Antiwar Movement in East Germany", in Andreas W. Daum, Lloyd C. Gardner, and Wilfried Mausbach (eds), America, The Vietnam War and the World: Comparative and International Perspectives (Cambridge, 2003), pp. 299-3 9. 38. Réunion de la présidence, Santiago de Chile, 4-9 October 1972, Archives départementales de la Seine-Saint-Denis, Bobigny, Conseil Mondial de la Paix, I 86 J I I.

39. Conférence internationale de solidarité avec le people chilien, Helsinki, 29 November 1973 , Archives départementales de la Seine-Saint-Denis, Bobigny, Mouvement de la Paix, I70 J I60.

40. The Chilean delegation included Volodia Teitelboim, Carlos Parra (representative to the Socialist International), and diplomats from the UP government in Sweden, Hungary, and Yugoslavia: Informationszentrum des Weltfriedensrates, Chile ist nicht allein. Internationale Solidaritätskonferenz für das Chilenische Volk, Helsinki, 29-30 September 1973; Socialist Affairs, 23:6 (1973), p. I Iо. 
solidarity with Chile into campaigns for East-West cooperation. During the World Congress of Peace Forces staged in Moscow in October 1973, hundreds of representatives involved in campaigns on behalf of European security and cooperation since the late i960s turned solidarity with Chile into a symbol that showcased the necessity of East-West détente to combat fascism. ${ }^{4 \mathrm{I}}$ The conference was at the roots of an International Commission of Inquiry into the Crimes of the Military Junta, which, in cooperation with leading members of the deposed Chilean Popular Unity, staged a series of international campaigns against Pinochet over the I 970 s and early I $980 .^{42}$ Similarly, in Paris in July 1974, delegations from "Socialist Europe" - on both sides of the Iron Curtain - staged a "Pan-European Conference of solidarity with Chile" under the leadership of the French communists and socialists. ${ }^{43}$ It aimed to revive in Europe the Popular Unity crushed in Chile. Appeals for East-West détente were a feature of campaigns by many national and local Chile solidarity committees in Europe, which emerged in quarters close to the peace movement.

Both networks and ideas allowed East and West to come together in campaigns on behalf of Chile. Crucially, there was the long-standing relationship between communist parties in Europe and the Chilean socialist and communist parties - which had formed the axis of Allende's Popular Unity. As mentioned earlier, these relations were strengthened after the coup, and stand out against the lack of information and connections in Western Europe in the first few months after the coup. Many Social-Democratic trade unions and parties in Western Europe had maintained only tenuous relations with the Popular Unity coalition in Chile prior to I973. There had, it is true, been some occasional festivities and visits, such as François Mitterrand's visit to Chile in I97I and the meeting of the Socialist International's bureau in Santiago in February $1973 .{ }^{44}$ Yet, the contacts of the Socialist International mainly proceeded through the small Chilean Radical Party, whereas the efforts of the Central Única de Trabajadores de Chile (CUT) - one of the pillars of the Chilean Popular Unity - at cooperation with Western Europe's Social-Democratic trade unions had been hampered by the scepticism of the anti-communist leadership of the International

41. World Congress of Peace Forces 1973. Bulletin, 2, 27 October 1973, p. I; Moscow Conference of Peace Forces, Commission No. I4, Chile, Report, I973, pp. 3-4, Archives Isabelle Blume, CarCob (Brussels).

42. Linda Heinonen, "Finland: Popularizing Chile", in Christiaens et al., European Solidarity with Chile, pp. 257-274, 267.

43. Note on the cooperation with Chile Democrático and report of the meeting in Rome of 28 May 1974, May 1974, Unclassified archives CEAL, Brussels; Pan European Conference Chile Solidarity, 6-7 July 1974, Archives Jef Houthuys, KADOC, no. 230.

44. Zourek, "Czechoslovak Policy Towards Chile in the I970s and I980s". 
Confederation of Free Trade Unions (ICFTU). ${ }^{45}$ In September 1973, it was an atmosphere of confusion that reigned even among established organizations such as Amnesty International and international social democracy, which lacked partners on the ground, avenues for organizing solidarity, and information. Also, Christian-Democratic trade unions and parties in countries such as the Netherlands, Italy, and Belgium were caught by a lack of information, due to the divided response of Chilean Christian Democrats to the new regime. Pinochet even found some of his most important apologists in Christian-Democratic circles in Western Europe: conservatives opposed asylum policies towards "radical" Chilean refugees in Europe, and did not want to jeopardize the survival of Chilean Christian democracy under the conditions of the new Pinochet regime. ${ }^{46}$ Against this backdrop, the contacts of communist parties and international organizations such as the World Peace Council, the International Union of Students, and the World Federation of Trade Unions with Chilean exiles buttressed the legitimacy and appeal of communist-led campaigns. In the months following September 1973, the World Federation of Trade Unions financed the tour of high-ranking CUT representatives from Prague across Western European trade union quarters. ${ }^{47}$ This gave way to new contacts between Chilean exiles and Western European NGOs and social movements, including the ICFTU and Amnesty International. Similarly, with the support of the International Union of Students in November I973 leaders of the Chilean student movement toured Finland, the UK, Poland, Czechoslovakia, Switzerland, and West Germany. ${ }^{48}$ Chilean exile organizations operating in Eastern Europe became key sources of information about the situation inside Chile - even for local groupings in the West. Chilean exiles supported this solidarity culture that brought East and West together. Nueva Canción groups performed on both sides of the Iron Curtain, just as visits of leading exiles of the Popular Unity and representatives of Chile Democrático, such as Allende's widow Hortensia, connected campaigns in the West and the East of the continent (see Figure I). Many of these initiatives were supported by Eastern European regimes, and most notably

45. Kim Christiaens, "The Difficult Quest for Chilean Allies: International Labor Solidarity Campaigns for Chile in the I 970 s and I980s", in Christiaens et al., European Solidarity with Chile, pp. 97-I 29.

46. See for instance Felix A. Jiménez Botta, "The Foreign Policy of State Terrorism: West Germany, the Military Juntas in Chile and Argentina and the Latin American Refugee Crisis of the 1970s", Contemporary European History (first view, 2018), pp. I-24; Georg Dufner, "West Germany: Professions of Political Faith, the Solidarity Movement and New Left Imaginaries”, in Christiaens et al., European Solidarity with Chile, pp. I63-I 86.

47. Agustín Muñoz, Vision de los Sindicatos Chilenos. Treinta Años de relaciones profesionales (Barcelona, 1985), pp. 206-215.

48. Chile: News Service, nos I9-20, 1973, p. 9. 


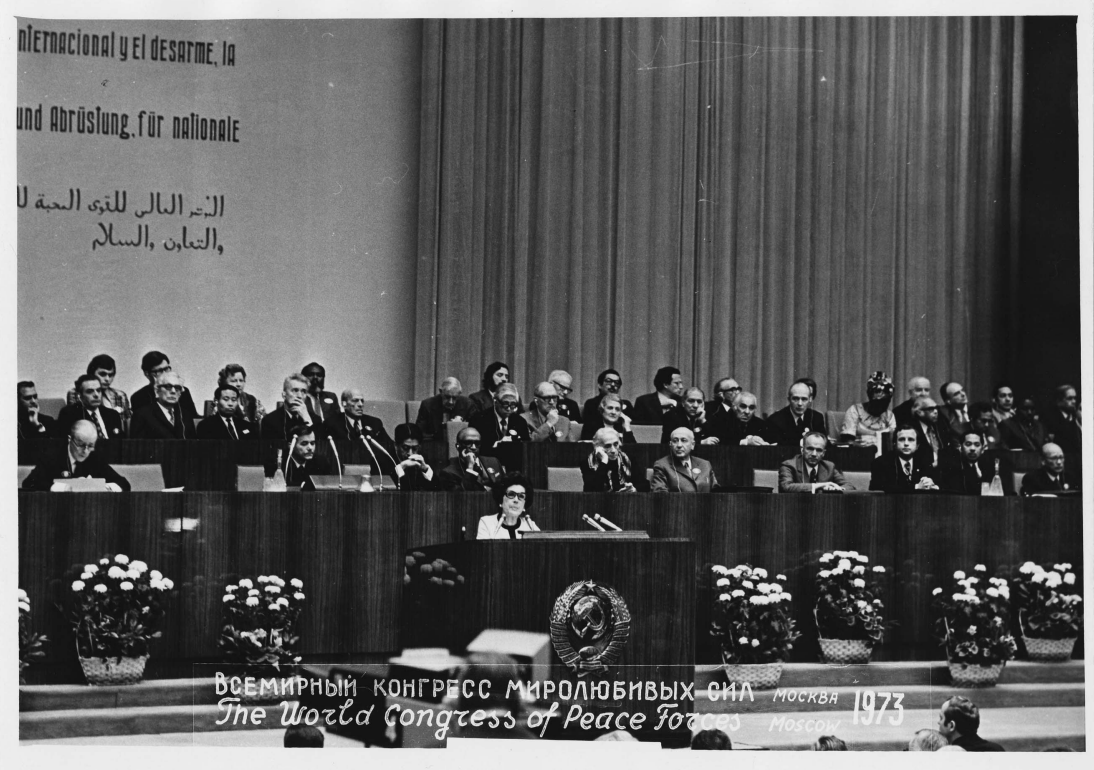

Figure I. Large-scale international conferences staged by Soviet-sponsored organizations provided a global forum to Chilean exiles, and cultivated the nexus between solidarity with Chile and East-West détente. Picture of Allende's widow Hortensia speaking to the World Congress of Peace Forces in Moscow in October 1973.

Modern Greek Archive, King's College, London, CHRON VII. Used by permission.

by East Germany. The latter's high profile - such as its role in disseminating covert information from Chile - cannot be separated from its policies aimed at gaining recognition and support in Western Europe. ${ }^{49}$ Although the engagement in campaigns on behalf of Chile varied across Eastern bloc countries, communist solidarity with the Third World was, in sum, not simply a matter of "shaming the West", as traditionally argued, but was also inspired by policies towards cooperation with Western Europe.

Communist campaigns were speaking a language of human rights and humanitarianism. The World Peace Council staged campaigns for the release of the imprisoned Chilean Communist Party leader Luis Corvalán that resonated all over Western and Eastern Europe, among Christian Democrats, human rights NGOs, and Social Democrats. ${ }^{50}$ In the summer of 1975, with the support of communist parties, CUT representatives launched the initiative for an international relief campaign for Chilean

49. Michal Zourek, Checoslovaquia y el Cono Sur 1945-1989. Relaciones políticas, económicas y culturales durante la Guerra Fría (Prague, 2014), p. 173.

50. Rupprecht, Soviet Internationalism, p. 280. 
children. Modelled upon the example of a similar campaign for Vietnam some years earlier, this "Boat for Chile" campaign coordinated by Secours Populaire Français mobilized trade unions in Western and Eastern Europe, collecting about $\mathrm{I} 62$ tons in relief (including food and clothes). ${ }^{51}$ Conferences staged by the World Peace Council linked national solidarity campaigns to actions at the level of the UN and, most notably, the ILO. Not an abstract legal framework, but anti-fascism was the dominant framework for these human rights campaigns. The idea of an anti-fascist struggle cultivated a common identity between Europe - East and West - and Chile, and erected a bridge between Pinochet's Chile and Europe's past. Chile became a toehold to cultivate the memory of World War II in Europe. Campaigns represented Pinochet and his uniformed soldiers as SS officers, and when the new Chilean ambassador to France arrived in Paris, activists hoisted the Nazi flag. ${ }^{52}$ Chilean exiles contributed to this connection: iconic figures of the Chilean opposition, such as Allende's widow and daughter, visited World War II memorials in the West and East, and when Chile Democrático launched appeals for international solidarity, it did this by calling for the formation of an "anti-fascist front" after the example of the resistance against Nazi Germany. ${ }^{53}$

\section{THE SOUTHERN EUROPEAN CONNECTION: IMAGINING ONE COMMON ZONE OF FASCISM}

Solidarity with Chile offered a projection screen not only for the past, but also for protesting against the stamina and perceived resurgence of fascism in Europe at the beginning of the I970s - which communist propaganda touted as a major threat for East-West détente. This becomes clear in the potent connection that emerged between campaigns against what were dubbed "fascist" dictatorships in Southern Europe and those on behalf of Chile during the I970s. Campaigns against Pinochet intertwined with those against the long-standing authoritarian regimes in Spain and Portugal and the military junta that had ruled over Greece since the April I 967 coup, even more so than with campaigns against other dictatorships in the Third World.

Campaigns against the authoritarian regimes of Spain and Portugal were slow to mobilize European social movements in the first two decades of the

5. Boat for Chile, 1976, ICFTU, no. I499; A Boat for Chile, 1976, Antiimperialistisches Solidaritätskomitee, IISH, Amsterdam, no. 76.

52. The Chile Monitor. A Bulletin of News on Chile: A Joint Production of the Chile Information Bureau, The Chile Solidarity Campaign, Chile Lucha, 4 (March I974), p. 2 I.

53. "Aux peuples pour le Chili - Appel de Rome I 8 September 73", in Cabiers Marxistes, I 8 (July-September 1973). Archives CEAL, Brussels; Declaration of the Chilean Left from Paris, I 2 February 1974; ibid., Letter from Jorge Arrate, February 1974. 
end of World War II. ${ }^{54}$ The association of the main Spanish and Portuguese opposition movements - headquartered in Eastern Europe - with the Soviet Union, as well as their Stalinist tendencies, had made them an unattractive cause for the Western European left, especially against the backdrop of the Cold War in the late I940s and I950s. 5 "Yet, from the early I960s, and in the wake of a growing focus on East-West détente, support for the Spanish and Portuguese opposition and protest against human rights violations committed in the name of anti-communism became a symbol for the European left to denounce the "Cold War" and to defy the international status quo, which ascribed Spain and Portugal to the Western bloc. ${ }^{56}$ "Amnesty" campaigns staged by communist parties and human rights NGOs saw the plight of political prisoners and the ban on communist parties as a symbol of the antithesis between anti-communism and human rights. ${ }^{57}$ This also became clear in the reactions against the 1967 coup by right-wing military officers in Greece. Anti-junta solidarity campaigns were inspired not only by the vision that Greece and, by extension, Western Europe were a victim of US colonialism and imperialism, but also by the revulsion of the anticommunist discourses of the Greek junta and its apologists in the West, which claimed that communism was a threat and "communists were beasts". ${ }^{8}$ In the late I960s, Social Democrats and communists united in campaigns on behalf of democracy and human rights in Greece, and welded protest against "fascism" in Southern Europe to campaigns on behalf of European security and cooperation. Campaigns benefited from the growing focus on the Third World: they cultivated the connection between two peripheries of "middling development" that were seen as one "zone of fascism" and as victims of American imperialism, neo-colonialism, and multinational corporations. ${ }^{59}$

54. Víctor Fernández Soriano, Le fusil et l'olivier. Les droits de l'Homme en Europe face aux dictatures méditerranéennes (1949-1977) (Brussels, 2015); Pedro Aires Oliveira, "A Sense of Hopelessness? Portuguese Oppositionists Abroad in the Final Years of the Estado Novo, 1968I974", Contemporary European History, 26:3 (2017), pp. 465-486.

55. Pilar Ortuño Anaya, European Socialists and Spain: The Transition to Democracy, 1959-77 (Basingstoke, 2002), p. I35.

56. Maud Bracke, Which Socialism, Whose Détente: West European Communism and the Czechoslovak Crisis of 1968 (Budapest, 2007), p. 90.

57. Tom Buchanan, "Human Rights, the Memory of War and the Making of a 'European' Identity, 1945-75", in Martin Conway and Kiran Klaus Patel (eds), Europeanization in the Twentieth Century: Historical Approaches (Basingstoke, 2010), pp. I57-171, I64-166.

58. Kim Christiaens, "'Communists are no Beasts'. European Solidarity Campaigns on Behalf of Democracy and Human Rights in Greece and East-West Détente in the 1960s and Early 1970s”, Contemporary European History, 26:4 (2017), pp. 62 I-646.

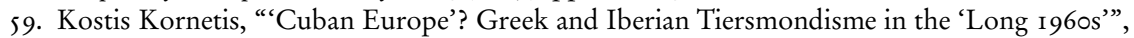
Journal of Contemporary History, 50:3 (2015), pp. 486-5 is; Iván Harsányi, “A chilei és a dél-európai baloldal közti kapcsolat és kölcsönhatás”, Múltunk, 4 (2008), pp. 245-255, 246-247. 
Likewise, anti-fascism, anti-colonialism, and anti-imperialism underpinned the connection between Chile and Southern Europe after September 1973, when international campaigns on behalf of Chile became entangled with resistance against authoritarian regimes in Portugal, Spain, and Greece. When the Social-Democratic and Christian international trade union movement staged international campaigns on behalf of Chile in the autumn of I973, they did this by explicitly referring to the plight of Southern Europe, calling upon the governments of the European Economic Community to see in Spain, Greece, and Portugal another Chile, and to rebuff these countries' rapprochement policies. ${ }^{60}$ In many countries, campaigns against the Portuguese, Greek, and Spanish dictatorships turned into sites for anti-Pinochet activism. Social-Democratic trade unions used campaigns on behalf of Portugal and Spain as an example to establish a committee to aid the clandestine Chilean labour movement. ${ }^{6 \mathrm{I}}$ The image of one common struggle in Chile and Southern Europe connected even diverse and opposed groupings, such as trade union movements, communists, and New Left radicals. The fall of Allende brought back memories of the failure of the Popular Unity in Spain during the I930s, and was seen as another "socialist dream transformed into a nightmare". ${ }^{62}$ Chilean exiles and the Greek socialist exile leader Andreas Papandreou were put together on the same podia, and their struggle was framed as a common battle of "socialism against fascism". ${ }^{63}$

Chronology, too, brought Southern Europe and Chile together after 1973. Domestic and international protest against the undemocratic regimes in Europe's southern tier expanded simultaneously with the Chilean crisis from the autumn of I 973 onwards. In November I973, the crushing of the polytechnic uprising in Athens, which ushered in a new military coup by Dimitrios Ioannidis, inspired a lot of reactions in Western European leftist quarters and notably among youth movements. Some months later, the execution of the Catalan anarchist Salvador Puig Antich by the Franco regime stirred the international public. ${ }^{64}$ The attention paid to Southern Europe's dictatorships grew due to the protest elicited by their growing efforts at cooperation with the European Communities. The plight of Chile and Southern Europe became a symbol to discredit and delegitimize

60. Christiaens, "The Difficult Quest for Chilean Allies".

6I. Brief notes on the evolution of the works of the ICFTU/CUT Chile coordinating committee, ICFTU, IISH, no. 1489 .

62. Joseph L. Nogee and John W. Sloan, “Allende's Chile and the Soviet Union: A Policy Lesson for Latin American Nations Seeking Autonomy”, Journal of Interamerican Studies and World Affairs, 2 1:3 (1979), pp. 339-368, 363.

63. PAK Newsletter, February, 3:2 (1974), p. I.

64. Actions on behalf of Salvador Puig Antich, 1973-1974, Documentation Collection Dutch Solidarity Movements, IISH, no. I60. 
East-West conflicts from which fascist leaders such as Caetano in Portugal, Franco in Spain, and Pinochet drew their legitimacy. Spanish, Greek, and Portuguese oppositionists at home and in exile entered not only communist-led peace campaigns, they were also key in the formation of a common identity with the Chilean left. ${ }^{65}$ Spanish exiles organized solidarity committees on behalf of the Chilean opposition in several countries. ${ }^{66}$ In Sweden, for instance, by 1972 Spanish republican exiles had already participated in founding a national solidarity committee in support of the Popular Unity, and this engagement continued after the events of $1973 .{ }^{67}$ This Spanish interest was, to a large extent, related to migration: republicans had fled to Chile after the end of the civil war and hundreds of thousands of Spanish migrants went to Latin America from the 1950s. ${ }^{68}$ Also, Greek oppositionists were keen to entangle their cause with resistance against Pinochet: in the autumn of 1973 , Greek students proclaimed their solidarity with Allende in the streets of Athens, as did leading figures of the Greek resistance in Western Europe - such as Mikis Theodorakis and George Moustaki. ${ }^{69}$ Andreas Papandreou, and the Pan-Hellenic Liberation Front he coordinated from Stockholm, regularly professed their solidarity with the Chilean resistance, stressing the need for a new socialism that reorganized itself outside the state system..$^{70}$ Delegations of the Greek left presented themselves as troubadours of international solidarity with the Chilean resistance during international conferences organized by the World Peace Council, and initiated joint campaigns. ${ }^{71}$ In sum, the Chilean drama was a concern that appeared to blur the highly divergent strategies of Southern European opposition movements, and served to dramatize their mission in a context of normalization policies. ${ }^{72}$

65. On the integration of Southern European oppositionists in campaigns for European security and cooperation, see for instance: Assembly of public opinion about European security and cooperation, 2 June 1972, International Meetings and Solidarity, IISH, no. 73.

66. Bart Latré, Strijd E inkeer. De kerk-en maatschappijkritische beweging in Vlaanderen (Leuven, 20I I), p. 226.

67. Fernando Camacho Padilla. "Las relaciones entre Chile y Suecia durante el primer gobierno de Olof Palme, 1969-1976", Iberoamericana, 7:25 (2007), pp. 65-85, 73.

68. Julio Gálvez, Winnipeg. Testimonios de un exilio (Santiago de Chile, 20I 2); Joe Foweraker, Making Democracy in Spain: Grass-Roots Struggle in the South, 1955-1975 (New York [etc.], 2002), p. 64 .

69. L'autre Grèce. Supplément au No. II-I2 (ig November 1973), p. I4.

70. Eugénia Palieraki, “'Le Chili est proche’. Les mouvements antidictatoriaux grecs et les septembres chiliens”, Monde(s), 2:8 (2015), pp. 45-64.

7I. L'autre Grèce. Supplément au No. I I-I2, p. I4; Kostis Kornetis, Children of the Dictatorship: Student Resistance, Cultural Politics, and the "Long I960s" in Greece (New York, 201 3), pp. 247248; PAK Newsletter, 3:2 (February I974), p. I.

72. Christian Salm, Transnational Socialist Networks in the 1970s: European Community Development Aid and Southern Enlargement (Basingstoke [etc.], 2016). 


\section{CHILEANS TURN TO SOUTHERN EUROPE}

Yet, Chileans, too, contributed to the connection between the overthrow of Allende and the plight of Southern Europe. Already prior to 1973, in addition to their contacts with the Spanish left, Chilean communists and socialists had mobilized against the anti-communist repression in Greece after the end of the Greek civil war in 1949. Pablo Neruda, the artistic icon of the Popular Unity, had been involved in campaigns over Greek children and refugees that were hosted in Eastern Europe after the Greek civil war. He composed an anthology of Greek poetry in 1968 on the invitation of East German solidarity movements with Greece. ${ }^{73}$ Stationed in Paris as Allende's ambassador to France, Neruda collaborated with the exiled Greek artist Mikis Theodorakis. After 1973, East Berlin became a meeting point between Chilean exiles and Greek opposition networks, such as the Central Council of the Greek Anti-Dictatorship Committees Abroad. ${ }^{74}$ When the Chilean communist leader Volodia Teitelboim addressed international audiences in the autumn of 1973 , he related the events in Chile above all to the 1967 coup in Greece, focusing on the involvement of the US and anti-communism that served to legitimize repression, imperialism, and fascism. ${ }^{75}$ The focus of Chilean exile organizations on Southern Europe expanded when the authoritarian regimes collapsed unexpectedly from I974 onwards, first in Portugal, then in Greece, and eventually in Spain.

Significantly, the Rome-based international network of Chile Democrático planned in cooperation with the World Peace Council its major international conferences in Southern European locales, including Lisbon (September 1974), Athens (November 1975), and Madrid (November I978). First, there was the impact of the events in Portugal after the 1974 Carnation Revolution, and most notably the inclusion and eventual exclusion of Portuguese communists in the ensuing transition to democracy. From 1974, the Portuguese Communist Party under the leadership of Alvaro Cunhal compared the reactionary forces and CIA involvement that crushed the Popular Unity government in Chile with efforts to break the unity between the Portuguese armed forces and the "Portuguese people" in the revolutionary government that included the Communist Party and symbolically withdrew the Portuguese ambassador to Chile. ${ }^{76}$ Cunhal was

73. David Schidlowsky, Neruda y su tiempo: 1950-1973 (Santiago, 2007), pp. I 2 I0-I 2 I I.

74. Andreas Stergiou, "Kommunistische Realpolitik. Das bizarre Verhältnis der SED zur Kommounistikó Kómma Elládas (1968-1989)”, in Arnd Bauerkämper and Francesco Di Palma (eds), Bruderparteien jenseits des Eisernen Vorhangs. Die Beziehungen der SED zu den kommunistischen Parteien West- und Südeuropas (I968-1989) (Berlin, 20I I), pp. 226-242.

75. World Congress of Peace Forces 1973, Bulletin, 3 (3 I October 1973), p. 4.

76. Chile Democrático. Boletín Informativo, 8 June 1974. 


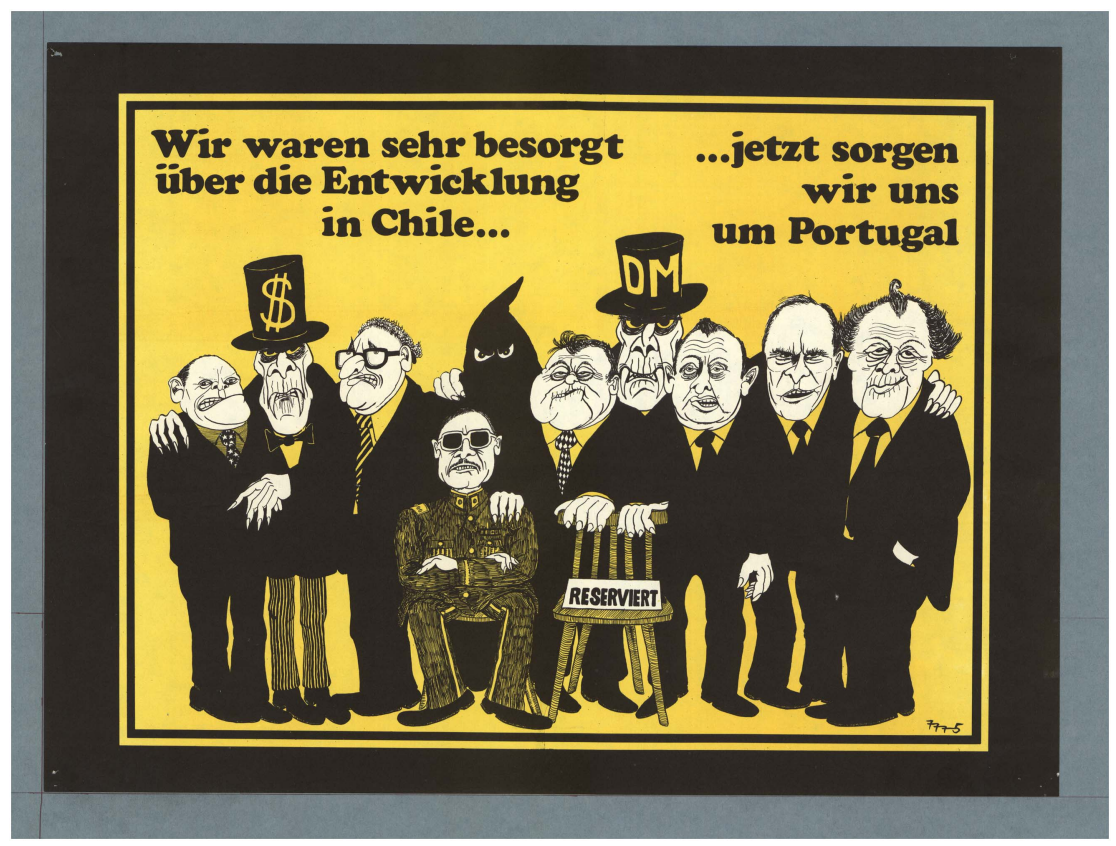

Figure 2. Anti-communist involvement in Portugal by the US and its Western European allies after the 1974 Carnation Revolution gave way to comparisons with the overthrow of Allende and the fear of "another Chile" in Europe.

IISH collection.

not the only one to see such parallels between Chile and Portugal. ${ }^{77}$ When the Portuguese communists were excluded from the Portuguese government and the socialist Mario Soares took over the reins of government, the European radical left was quick to see in what they called the "coup" by Soares a reminder of the complicity of Christian democracy, the US, and multinational corporations in the overthrow of Allende two years earlier (see Figure 2). ${ }^{78}$ In the UK, Trotskyist radicals stressed the similarities between the involvement of ITT and other multinationals in Portugal and Chile in crushing workers' revolutions, and denounced the ways in which the West used anti-communism to legitimize its involvement. ${ }^{79}$ They attacked the Eurocommunist support of the French and Italian communist

77. Mario Del Pero, “'Which Chile, Allende?' Henry Kissinger and the Portuguese Revolution”, Cold War History, i I:4 (201 I), pp. 625-657.

78. David L. Raby, Fascism and Resistance in Portugal: Communists, Liberals and Military Dissidents in the Opposition to Salazar, I94I-I974 (Manchester [etc.], I988), p. I4.

79. Portugal, Spain. Towards the Iberian Socialist Revolution. International Marxist Group. London, September 1975, Papers Alan Clinton, Modern Records Centre (Warwick University), MSS. 539/4/14. 
parties for Soares. This was a message that rendered the Portuguese events also relevant to Chilean exiles, for whom it offered a means to discredit the Eurocommunist idea that Western democracy and socialism were compatible and to legitimize their cooperation with Eastern European state socialism. The question of how to combine democracy and socialism after "fascism" also underpinned Chilean interest in Greece, where the military junta collapsed peacefully after the crisis over Cyprus in 1974. In Athens, in November 1975, together with the World Peace Council and the Greek Communist Party Chile Democrático organized a large-scale "World Conference of Solidarity with the Chilean People". ${ }^{80}$ The event was attended by icons of the Greek and Chilean left as well as by hundreds of representatives from Eastern and Western Europe, and it led to campaigns and appeals on behalf of human rights in Chile at the level of the UN. ${ }^{81}$

\section{BETWEEN TRANSITION AND REVOLUTION}

After the death of Franco in 1975, the negotiated transition to democracy in Spain was the most important example for Chilean exiles. Historians have amply analysed the impact of the "Spanish model" of a negotiated transition in terms of political strategies of fighting against Pinochet, ${ }^{82}$ but its effect on international solidarity campaigns on behalf of Chile was rather ambivalent. On the one hand, the end of the Franco regime stimulated new campaigns against Pinochet. ${ }^{83}$ Galvanized by the refusal of the government of Adolfo Suárez to back UN action against Pinochet, from 1977 Spanish oppositionists rallied massive support in campaigns that united the Spanish communist and socialist parties, Christian progressives, and trade union movements. With the support of the World Peace Council, Chile Democrático turned this national campaign into a global movement to isolate Pinochet and campaign on behalf of disappeared oppositionists in Chile. After a preparatory meeting in Benghazi in August 1978 - financed by the Libyan Gaddafi regime - Chile Democrático staged a world conference of solidarity with Chile in Madrid in November 1978, which was attended by delegations of human rights groups, Social Democrats, Christian

80. Conseil de continuation et de liaison du congrès mondial des forces de paix. Conférence internationale de solidarité avec le peuple chilien. Athènes du I 3 au I6 Novembre 1975 (Helsinki, 1975); Adam Feinstein, Pablo Neruda: A Passion for Life (London, 2005), p. 376.

81. Clodomiro Almeyda, Liberación y Fascismo (Mexico, 1979), pp. 79-86.

82. See for instance Kurt Weyland, Making Waves: Democratic Contention in Europe and Latin America Since the Revolutions of 1848 (New York, 2014), pp. 192-223; Hite, When the Romance Ended.

83. Héctor Gustavo Opazo Romero, Los actores no gubernamentales españoles ante el régimen militar de Augusto Pinochet (1973-1990). Apoyo a la democratización y defensa de los Derechos Humanos (Madrid, 2008). 
Democrats, and communist parties from all over the world ${ }^{84}$ Here, too, East-West détente and resistance against Pinochet were seen as two sides of the same coin. More generally, the transitions to democracy in Southern Europe stimulated Social-Democratic interest in Chile. Members of the Socialist International and Social-Democratic trade unions saw in the unforeseen collapse of Southern Europe's dictatorships a pretext to strengthen their ties with "moderate" oppositionists in Chile and other Latin American countries. From the mid-1970s, Mario Soares and his Spanish coeval Felipe González turned the attention of European Social Democrats to Latin America. Under the leadership of Willy Brandt, the Socialist International allied itself with left-wing struggles against "fascist" dictatorships in Latin America - such as in Argentina and Nicaragua. ${ }^{85}$ Still, anti-fascist solidarity coloured the understanding of human rights: as Socialist International general-secretary Bernt Carlsson declared when defending his organization's support for opposition movements in Latin America, Europe's experience of resistance against Nazism showcased the fact that human rights and armed resistance were not mutually exclusive. ${ }^{86}$ On the other hand, Chile stood quite awkwardly in this broadening interest in the potential for democracy and human rights in Latin America from the mid-I970s. Pinochet firmly held the reins of power, and domestic opposition was weakly organized. The model of a "negotiated transition" undermined the mission of exiles and international solidarity campaigns, which had played only a minor role in the downfall of authoritarian regimes in Southern Europe. Campaigns over Chile broadened their concern to include other countries in Latin America. In 1978-I979, the ICFTU's Chile Committee, established in 1974 to provide assistance to the Chilean labour opposition, became a Committee for the Defence of Human and Trade Union Rights in Latin America and was extended to include countries such as Colombia, Paraguay, and Nicaragua. ${ }^{87}$

Both the choice between a transition along the lines of the Spanish example, or armed revolution, and the thawing of détente increasingly divided Chilean exiles in the late I970s. ${ }^{88}$ The Chilean Socialist Party - the

84. Circular from Chile Democrático by Benjamin Teplizky, 9 June 1978, Private Archives Oxfam-Belgium, Brussels; Flash (World Confederation of Labour), No. 89, i November 1978, pp. $2-3$.

85. Fernando Pedrosa, "Redes transnacionales y partidos políticos. La Internacional Socialista en América Latina (I95 I-I99I)", Iberoamericana, I 3:49 (20I3), pp. $25-46$.

86. "Democracia - Violencia - Socialismo. Entrevista a Bernt Carlsson", Nueva Sociedad, 43 (1979), p. I09.

87. Committee for the Defence of Human and Trade Union Rights in Latin America, Santiago, I4-I 5 September i988, ICFTU, no. I488.

88. Victor Figueroa Clark, "Nicaragua, Chile and the End of the Cold War in Latin America", in Artemy M. Kalinovsky and Sergey Radchenko (eds), The End of the Cold War and The Third World: New Perspectives on Regional Conflict (London, 201 I), pp. 192-207. 
most important political movement in exile - witnessed a split between a tendency led by Clodomiro Almeyda, which allied with the Soviet camp, and a section dubbed "renovated socialists", under the leadership of secretary-general Carlos Altamirano, who left East Berlin and settled in France. ${ }^{89}$ Internationally, debates about the relationship with communists had a divisive impact on Social Democrats in Europe and their solidarity campaigns on behalf the Chilean opposition in the late I970s. Under the influence of the American Federation of Labor and Congress of Industrial Organizations (AFL-CIO), the ICFTU temporarily withdrew its support to the Chilean trade union movement in exile - which continued to cooperate with both the World Federation of Trade Unions (WFTU) and the Chilean communist and socialist parties, as well as with Scandinavian Social Democrats. ${ }^{9}$ In addition, there was the growing role of Christian democracy - which found for itself a new role as the Catholic Church in Chile and Christian-Democratic trade union leaders took a more active role in domestic opposition against Pinochet, as we will see in the next section. ${ }^{9 \mathrm{r}}$ More broadly, there was the decline of the European left's interest in the issue of Chile. In Western Europe, campaigns on behalf of Chile retreated in the late i 970 s to the quarters and offices of NGOs, party foundations, and local solidarity groups. The focus on Southern European models of transition signalled a broader shift away from Third World models of revolution - most notably the Vietnamese example - to what were seen as "European" examples of democratization.

After the 1975 "liberation" - or what was seen by many observers as the "conquest" of Saigon in 1975 - Chilean refugees became associated with Vietnamese boat people fleeing communism in Indochina: NGOs that had mobilized in support of Chilean refugees now hosted boat refugees fleeing communism in Vietnam..$^{22}$ From the mid-r970s, the socialist revolution advocated by Allende's Popular Unity and pursued by Chilean exiles appeared in a row of failed revolutions and wrecked non-alignment in the Third World. Many Chile campaigners - including Chilean exiles - shifted their hopes to national liberation movements in other countries of Latin America, most notably the Sandinista Liberation Front (FSLN) in

89. Jorge Arrate and Eduardo Rojas, Memoria de la Izquierda Chilena, Tomo II (1970-2000) (Barcelona [etc.], 2003), p. xxx; Javier Santiso, "La democracia como horizonte de espera y campos de experiencia. El caso ejemplo chileno", Revista de Ciencia Política, 21:2 (200I), pp. 69-100, 90-9I.

90. Christiaens, “The Difficult Quest for Chilean Allies".

91. Alan Angell, "International Support for the Chilean Opposition, 1973-1989: Political Parties and the Role of Exiles", in Laurence Whitehead (ed.), The International Dimensions of Democratization: Europe and the Americas (New York, 1996), pp. 175-200, I91-192.

92. Hugues Tertrais, "La Cimade, l'Indochine et ses réfugiés (1969-1979)", in Dzovinar Kévonian et al. (eds), La Cimade et l'accueil des réfugiés. Identités, répertoires d'actions et politique de l'asile, 1939-1994 (Nanterre, 2013), pp. 173-18 I. 
Nicaragua. ${ }^{93}$ Chilean exiles not only participated in the FSLN's armed struggle on the ground, they also became the pioneers of solidarity movements on behalf of the liberation of Nicaragua in many European countries. ${ }^{94}$ Others, by contrast, increasingly looked towards the plight of Eastern European dissidents.

\section{THE ANTI-TOTALITARIAN UTOPIA: CHILE AND EASTERN EUROPEAN DISSIDENTS}

Up until the mid-I970s, the cause of Eastern European dissidents and their struggle against "real existing socialism" received little attention from social movements in the West, with the short-lived indignation about the crushing of the Hungarian Revolution in 1956 and the Warsaw Pact invasion in Czechoslovakia in the summer of 1968 as the most notable exceptions. ${ }^{95}$ Eastern European dissidents faced effective repression at home, were weakly organized, and found little traction in the West. Their efforts to mobilize social movements in Western Europe were hampered by the spirit of East-West détente that inspired peace and disarmament movements, and even ushered in the ban on Eastern European exiles being members of international Social-Democratic movements. ${ }^{96}$ Campaigns on behalf of dissidents were overshadowed by issues in the Third World, such as the Vietnam War and anti-apartheid, which stressed the need to liberate the Third World from the burden of the East-West conflict. ${ }^{97}$ At some points throughout the I960s and I970s, Eastern European dissidents and their supporters in the West tried to change their fortunes by making inroads into

93. Clark, "Nicaragua, Chile and the End of the Cold War in Latin America"; Pascale Bonnefoy, Claudio Pérez, and Ángel Spotorno, Internacionalistas. Chilenos en la Revolución Popular Sandinista (Santiago, 2009).

94. Kim Christiaens, "Globalizing Nicaragua? An Entangled History of Sandinista Solidarity Campaigns in Western Europe", in Jan Hansen, Christian Helm, and Frank Reichherzer (eds), Making Sense of the Americas: How Protest Related to America in the 1980 s and Beyond (Frankfurt [etc.], 2015), pp. I I I-I73.

95. See for instance Robert Brier (ed.), Entangled Protest: Transnational Approaches to the History of Dissent in Eastern Europe and the Soviet Union (Osnabrück, 2013); Marc Lazar, "La gauche ouest-européenne et l'année I968 en Tchécoslovaquie. Les cas français et italien”, in Antoine Marès (ed.), La Tchécoslovaquie, sismographe de l'Europe an XXe siècle (Paris, 2009), pp. 177-193.

96. See for instance Letter from the Hungarian Social-Democratic youth movement, May I970, IUSY archives, IISH, no. I 822 .

97. Jacques Rupnik, "The Legacies of Dissent: Charter 77, the Helsinki Effect, and the Emergence of a European Public Space", in Friederike Kind-Kovács and Jessie Labov (eds), Samizdat, Tamizdat, and Beyond: Transnational Media During and After Socialism (New York, 2013), pp. 316-332, 323-324. 
campaigns over the Third World and anti-colonialism..$^{98}$ The Chilean crisis of 1973 did indeed become a projection screen for a number of Eastern European dissidents and their niche following in Western Europe. During the World Congress of Peace Forces in Moscow in 1973, a number of Western European groups, including War Resisters' International, Pax Christi, the Catholic Youth Council, and the Bertrand Russell Peace Foundation, used communist campaigns on behalf of Chile to draw attention to the violations of human rights in the Soviet Union and other socialist countries - demanding the liberation of political prisoners and respect for the principles of the Universal Declaration of Human Rights. ${ }^{99}$ In the summer of 1974, thirty Czech dissidents launched a Manifesto for Chile, in which they drew parallels between the Husák and Pinochet regimes. ${ }^{100}$ Jiří Pelikán and other Czechoslovak dissidents in exile established committees for the denunciation of repression in Czechoslovakia that included leftist intellectuals, who, at the same time, staged solidarity campaigns on behalf of Chile. ${ }^{\text {IOI }}$ It was a typical example of how dissident cultures used official discourses and propaganda of solidarity with the Chilean resistance to push their communist regimes on their claims of democracy and human rights. The Cold War, superpower involvement and imperialism, economic underdevelopment, as well as the absence of national self-determination were, for these groups, at the root of "totalitarian" regimes in Eastern Europe, Chile, and other Third World countries. ${ }^{102}$

Yet, until the late I970s, such connections were fiercely contested. First, the Chilean events did not foster but, in contrast, hampered the cause of Eastern European dissidents. Eastern European dissidents were far from being a homogenous category, and they failed to present themselves unambiguously in support of a defeated Chilean left that had nurtured its ties with the Soviet camp under Allende and continued to do so after the coup. Aleksandr Solzhenitsyn and other Eastern European dissidents rebuffed comparisons between their struggle against Soviet repression and the plight of Chile. ${ }^{103}$ Some of them openly sympathized with the anticommunist Pinochet regime, just as they, for instance, supported the

98. See also the many references to Southern Europe and the Third World in Robert Gildea, James Mark, and Anette Warring (eds), Europe's 1968: Voices of Revolt (Oxford, 2013).

99. Congrès mondial des forces de paix. La liberté de dissentiment. Un appel. Archives Départementales de la Seine-Saint-Denis, Bobigny, Mouvement de la Paix, I70 J I77.

I00. Karel Kovanda, “A Document of Our Time”, New York Review of Books, 3 I October 1974. ıог. Jiři Pelikán (ed.), Ici Prague, l'opposition intérieure parle. Documents présentés par Jǐri Pelikán (Paris, 1973), pp. 42 I-422.

I02. Robert Brier, "Adam Michnik's Understanding of Totalitarianism and the West European Left: A Historical and Transnational Approach to Dissident Political Thought", East European Politics and Societies, 25:2 (201 I), pp. 197-2 I 8.

I03. Tobias Rupprecht, "Formula Pinochet: Chilean Lessons for Russian Liberal Reformers during the Soviet Collapse, 1970-2000", Journal of Contemporary History, 51:I (2016), pp. I65-186, I72; 
apartheid regime in South Africa or Franco in Spain. ${ }^{104}$ The Pinochet regime strengthened its domestic and international profile as a bastion of anti-communism when it released the communist Luis Corvalán in exchange for the liberation of the Soviet dissident Vladimir Bukovsky in 1976. ${ }^{105}$ Eastern European dissidents were not only instrumentalized by Pinochet and its anti-communist apologists in the West, ${ }^{\mathrm{I}}{ }^{\mathrm{O}}$ they were also discredited by communist propaganda that portrayed them as supporters of "fascism". ${ }^{\text {Io }}$

The solidarity of Eastern European dissidents with Chile was overshadowed by much more powerful currents of pan-European cooperation in the I970s, as well as by the alliance between the Soviet camp and the Chilean opposition. From a Chilean perspective, an alliance with dissidents in Eastern Europe would be a very awkward issue, since the leading political parties in exile were headquartered in Eastern European locales and there received material and political support. Chilean exile organizations, such as Chile Democrático and CUT's Comité Exterior (CEXCUT), opposed the efforts of Western European campaigners aiming to bracket them together with Eastern European dissidents. When, in 1978, peace campaigners conceived plans for a joint commemoration of the tenth anniversary of the Prague Spring and the fifth anniversary of the Chilean coup, their plans met with a veto from Chilean exiles. ${ }^{108}$ The same year, by contrast, the broad interest of various kinds of Western European solidarity movements in an international human rights campaign on behalf of the desaparecidos in Chile, staged by the World Peace Council in cooperation with Chile Democrático, showed that East-West cooperation was a far more attractive perspective to gain international attention. During this campaign, Chilean exiles - including mothers and family members of

Christopher Andrew and Vasili Mitrokhin, The World was Going our Way: The KGB and the Battle for the Third World (New York, 2005), p. 470.

I04. See for instance Mirosław Dzielski, Odrodzenie ducha - budowa wolności. Pisma zebrane (Kraców, 1995), p. 208; Adam Michnik, Letters from Freedom: Post-Cold War Realities and Perspectives (Berkeley, CA, 1998), p. 99.

I05. Olga Ulianova, "Corvalán for Bukovsky: A Real Exchange of Prisoners during an Imaginary War. The Chilean Dictatorship, the Soviet Union, and US Mediation, 1973-1976", Cold War History, I4:3 (2014), pp. 315-336.

106. Jensen, The Making of International Human Rights.

107. Rupprecht, "Formula Pinochet", p. 172; Andrew and Mitrokhin, The World was Going our Way, p. 470.

I08. Kim Christiaens, "From the East to the South, and Back? International Solidarity Movements in Belgium and New Histories of the Cold War, I 950s-1 970s", Dutch Crossing, 39:3 (201 5), pp. I87-203; Alfonso Salgado, "Communism and Human Rights in Pinochet's Chile: The 1977 Hunger Strike against Forced Disappearance”, Cold War History, i 8:2 (2018), pp. г69-186. 
disappeared Chilean oppositionists - toured from East Germany across Western Europe, visiting church leaders, governments, and solidarity groups. ${ }^{\text {I09 }}$

\section{SOLIDARNOŚĆ AND CHILE}

Strikingly, the gap with Eastern European dissidents seemed to disappear from the early i 980 , when campaigns on behalf of the Chilean opposition became associated with the rise and fall of Solidarność in Poland. No other international issue in the r 980 s became so intimately connected with campaigns on behalf of Chile as the cause of Solidarność. The rise of Solidarność in the summer of 1980 triggered much interest in the West. Yet, it was especially its crushing under the Jaruzelski regime after the declaration of martial law in December 198I that mobilized Western solidarity on behalf of the Polish opposition. ${ }^{110}$

Viewed from a Cold War perspective, Poland and Chile seemed to inhabit different storylines: Solidarność was a Catholic trade union movement supported by Cold War warriors such as Reagan and Thatcher, two of Pinochet's apologists in the West who supported both his anti-communism and neo-liberal policies. ${ }^{\text {II }}$ By contrast with Chile, Poland had a communist regime which, together with other socialist states, supported the Chilean opposition. ${ }^{\mathrm{II} 2}$ Yet, upon the Polish crisis of December I98 I, international observers as well as Polish and Chilean oppositionists were quick to draw analogies between the dark-spectacled General Pinochet and his Polish coeval General Jaruzelski. ${ }^{I 13}$ The Polish events had a deep and divisive impact on the Chilean opposition: ${ }^{\mathrm{II} 4}$ the rise and crushing of Solidarność developed into a major flashpoint for debates about the relationship between socialism and democracy and about strategies of fighting Pinochet, which had been dividing the Chilean opposition at home and in exile since the late i970s. Whereas the Chilean Communist Party leader Luis Corvalán celebrated the Jaruzelski coup as a means of protecting socialism in Poland

109. Circular of the Comite Europe-Amérique Latine (CEAL), I September 1977, WCL, KADOC, no. I 3 .

I Io. Idesbald Goddeeris (ed.), Solidarity with Solidarity: Western European Trade Unions and the Polish Crisis, $1980-1982$ (Lanham, MD [etc.], 2010).

I I. Gregory F. Domber, Empowering Revolution: America, Poland, and the End of the Cold War (Chapel Hill, NC, 2014); Morris Morley and Chris McGillion, Reagan and Pinochet: The Struggle over US Policy toward Chile (Cambridge, 2015).

I I 2. Harmer, Allende's Chile.

I I 3. Brier, "Poland's Solidarity", pp. 99-го0.

I 4. Ignacio Walker, Socialismo y democracia. Chile y Europa en perspectiva comparada (Santiago, 1990), pp. I86-187. 
and continued cooperation with the Soviet camp, ${ }^{\text {II }}$ renovated socialists were keen to identify with Solidarność and to draw lessons from its rise and eventual banishment. ${ }^{116}$ As early as $198 \mathrm{I}$, the Chilean socialist exile Carlos Altamirano - who had left East Germany as a dissident in I979 travelled to Warsaw to meet with Wałęsa, express solidarity with the Polish opposition, and emphasize their common belief in the power of democracy, non-violent resistance, and a broad-based opposition. ${ }^{117}$ The coup of December I98I and subsequent repression in Poland was closely followed by the major exile organizations of the renovated socialists, Christian Democrats, and other exile organizations for whom the fate of Solidarność offered a means to distance themselves from pro-Soviet exile organizations and to reject the communist moniker that Chilean state propaganda and Pinochet apologists in the West conferred upon the Chilean opposition. ${ }^{\mathrm{I} 8}$

Chile and Poland emerged as a common struggle for workers' rights on the agenda of European social movements in the I980s (see Figure 3). As opposition parties were outlawed, trade unions and notably the Coordinadora Nacional Sindical (CNS) started to embody the domestic opposition against Pinochet in the late I970s and early i980s. The government's neoliberal policy and restrictive labour legislation, together with the economic crisis of the 1980 s, created a fertile breeding ground for them to rally broad sectors of society behind a programme for democracy and human rights. ${ }^{\text {II9 }}$ Along with the continuing repression, this restructuration of opposition around trade unions changed not only the nature and orientation of the international campaigns against Pinochet set up by Chilean exiles and their allies in Western Europe, but also made the parallels with the Polish trade union opposition more obvious. Within several days of Solidarność being banned, from his prison in Santiago the Christian textile worker and leading oppositionist Manuel Bustos sent a message of solidarity with Lech Wałęsa to the ICFTU meeting convened in Brussels to discuss campaigns in support of Solidarność. ${ }^{120}$ Solidarity with the Polish opposition became a potent symbol for the Chilean trade union movement,

I I 5. See for instance Chile-América, 76-77 (1982), p. 56; Convergencia. Revista del socialismo chileno y latinoamericano, 5-6 (1982), p. 23.

i 16. "Declaración sobre Polonia"; Chile-América, 76-77 (January-February-March i982), p. 7. i 17. Heraldo Muñoz, The Dictator's Shadow: Life Under Augusto Pinochet (New York, 2006), p. I 26; Walker, Socialismo y democracia, p. I87.

I I 8. "Nuestra solidaridad con el pueblo polaco", Convergencia, 5-6 (November 198 I-January 1982), pp. 29-30; Chile-América, 76-77 (January-February-March I982), pp. 35-36.

I 19. Peter Winn (ed.), Victims of the Chilean Miracle: Workers and Neoliberalism in the Pinochet Era, 1973-2002 (Durham, NC [etc.], 2004).

I 20. Chile-América, 76-77 (1982), p. 56. 


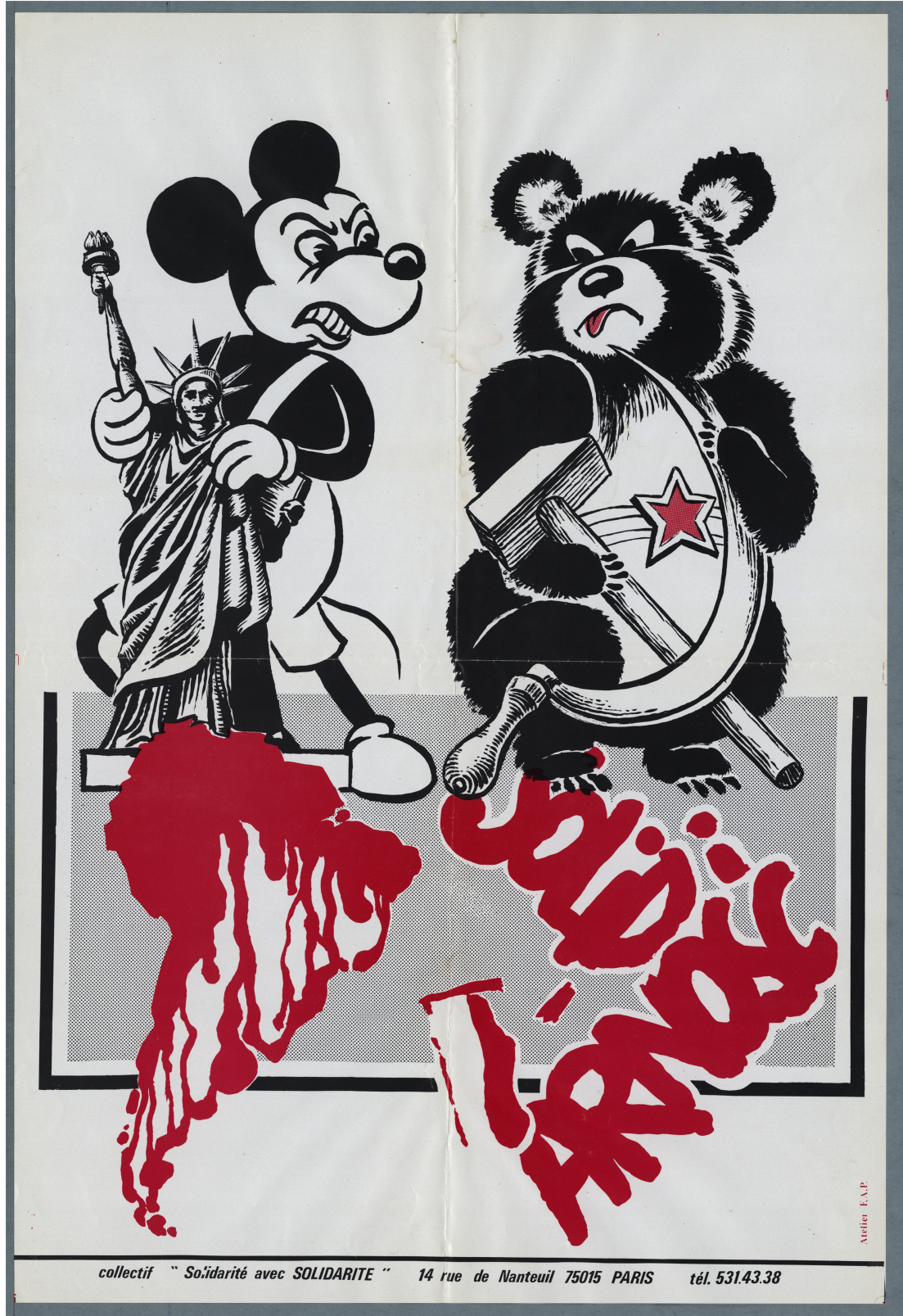

Figure 3. In the I980s, many solidarity campaigners represented Eastern Europe and Latin America as common victims of superpower imperialism. https://search.socialhistory.org/ Record/I483 I 77 IISH collection. 
especially because it caused the attention the Polish crisis received in the anti-communist propaganda of the Pinochet regime to backfire. ${ }^{\text {I2I }}$ The Chilean opposition even created its own version of Wałęsa: Rodolfo Seguel, the young trade union leader of the Comando Nacional de Trabajadores, which mobilized thousands of citizens in mass demonstrations and national strikes from I 983 onwards. Internationally and domestically, Seguel became known as a "Chilean Lech Wałęsa". ${ }^{\text {22 }}$

Conversely, the Polish opposition made inroads in human rights campaigns on behalf of Chile. ${ }^{123}$ In early 1982, Wałęsa answered the declaration of solidarity by Manuel Bustos by professing his support for the Chilean labour opposition against Pinochet and by denouncing the imprisonment of Bustos and the communist trade unionist Alamiro Guzmán. ${ }^{\text {I24 In December }}$ 1983, he invited Rodolfo Seguel to attend the Nobel Peace Prize award ceremony in Oslo. The most sustained cooperation between Polish and Chilean exiles emerged in Western Europe. In the summer of 1982, leading Polish exiles created the Solidarność Coordinating Office Abroad, which, from its headquarters in Brussels, served as the Polish opposition's international representation. ${ }^{\mathrm{I} 5}$ Inspired by the Polish example, the Chileans set up the Chile Labour Committee to function as a coordinating body for international solidarity campaigns on behalf of the Chilean labour opposition. ${ }^{\text {I26 }}$ Both the Chile Labour Committee and the Solidarność Coordinating Office Abroad were based in Brussels, and supported by the international trade union movement. ${ }^{127}$ Chileans and Poles issued joint solidarity declarations and featured together at international conferences, for instance in delegations sent to the annual conferences of the International Labour Organization in Geneva. Chile offered not only a toehold to universalize the cause of the resistance against Jaruzelski and to defy Cold War bipolarity, it also increased the tragic dimension of the Polish crisis. By flaunting Poland as another Chile, the Polish opposition aimed to

I 2 I. Huneeus, "Political Mass Mobilization", p. 207.

I 22. Jorge Edwards, "Chile. El difícil retorno a la democracia", Revista de la Universidad de México, 34 (1984), p. I2; Der Spiegel, 27 June 1983.

I 23. On Solidarność's contacts with Latin America, see Kim Christiaens and Idesbald Goddeeris, "Solidarność and Latin America in the I980s: Encounters, Conflicts and Failures", Archiv für Sozialgeschichte, 56 (2016), pp. 445-461.

I 24. Mary Helen Spooner, Soldiers in a Narrow Land: The Pinochet Regime in Chile (Berkeley, CA [etc.], I999), p. I68.

I 25. Idesbald Goddeeris, "Lobbying Allies? The NSZZ Solidarność Coordinating Office Abroad, I982-1989", Journal of Cold War Studies, I 3:3 (201 I), pp. 83-I 25.

I 26. Christiaens, "The Difficult Quest for Chilean Allies"; Free Labour World, 39I-392 (1983), p. 6.

I 27. Idesbald Goddeeris, "Ministerstwo Spraw Zagranicznych 'Solidarności'. Biuro Koordynacyjne NSZZ 'Solidarność', 1982-1989, część 2”, Pamięć i Sprawiedliwość, I:I I (2007), pp. 309-334, 343. 
undermine the growing voices within Europe and the US that started to tilt towards Jaruzelski's normalization policy in the mid-I980s. ${ }^{\text {I28 }}$

\section{THE LIMITS OF AN ANTI-TOTALITARIAN STRUGGLE}

This narrative of a common anti-totalitarian struggle in Chile and Poland remained deeply contested, however, partly because it had an obvious Cold War dimension: contacts between Polish and Chilean oppositionists were to a large extent set up by their common allies in the West - including the American AFL-CIO. ${ }^{\text {I29 }}$ The ICFTU and its Christian counterpart, the World Confederation of Labour, staged meetings with representatives of the Chilean and Polish opposition at local and international fora. ${ }^{1{ }^{\circ}}$ They brought Solidarność to Latin America to re-invigorate non-communist trade unions and to profile themselves, in rivalry with each other, as a "third way" between capitalism and communism. Pope John Paul II visited Chile in April 1987: he ignored the official programme and met with political opposition leaders and with representatives of all trade unions. ${ }^{\mathrm{I} I}$ Similarly, Chileans were brought into contact with Eastern European dissidents: Jorge Arrate, a former Popular Unity minister who became one of the leaders of the "renovated socialists" in exile, met with Eastern European dissidents in the Netherlands during his activities at the Institute for the New Chile, an initiative that aimed to unite the non-communist opposition and was financed by Western European Social Democrats. ${ }^{\mathrm{I} 2}$ Another constraint was that important currents within the Chilean political left in Western and Eastern European exile continued to identify with armed resistance or popular rebellion throughout the $1980 \mathrm{~s},{ }^{\mathrm{I} 33}$ and shared the criticism of many other political movements in the Third World - such as the ANC and the Sandinistas in Nicaragua - which labelled Solidarność and Eastern European dissidents instruments of US imperialism. ${ }^{134}$ The

I28. Peter Kornbluh, The Pinochet File: A Declassified Dossier on Atrocity and Accountability (New York, 2013).

I 29. See for instance Minutes of a talk with Lech Wałęsa by Günther Engelmayer, 20 December I983, Archives WCL, KADOC, no. 327.

I 30. Brier, "Poland's Solidarity", pp. 99-100.

I3 I. Christiaens and Goddeeris, "Solidarność and Latin America in the r980s".

I 32. Arrate and Rojas, Memoria de la Izquierda Chilena, p. 283; Perry, "With a Little Help from My Friends"”.

I33. Victor Figueroa Clark, "The Forgotten History of the Chilean Transition: Armed Resistance Against Pinochet and US Policy towards Chile in the I980s", Journal of Latin American Studies, 47:3 (201 5), pp. 49I-520; Christiaens, "Globalizing Nicaragua?”.

I34. Dieter Gawora, Lateinamerika hier. Zur Entwicklung der internationalen Solidaritätsarbeit in der Bundesrepublik. Entwicklungsperspektiven (Kassel, I984), pp. 77, 87; V. Santiago Pozas Pardo, Nicaragua (1979-1990). Actor Singular de las relaciones internacionales en el final de la guerra fría (Leioa, 2000), pp. $232 \mathrm{ff}$. 
majority of Chilean exiles stuck to the path of East-West détente and tried to embed the issue of Chile in the peace campaigns that mushroomed in the wake of the NATO Double Track decision across Europe. In September 1982, leading Chilean exiles - such as Hortensia Allende and Anselmo Sule - a Radical Party leader and vice-president of the Socialist International participated with representatives of the Polish Jaruzelski government, East Germany, the USSR, other Eastern European countries, and Western European solidarity groups in a conference of the International Commission of Inquiry into the Crimes of the Military Junta in Athens. ${ }^{135}$ In I983, when the anti-nuclear protests reached their zenith in Western Europe and the Chilean coup its tenth anniversary, Chile Democrático launched a campaign to allow the return of exiles to Chile under the significant slogan of "the right to live in peace". ${ }^{16}$ In Brussels, several thousand peace activists gathered at a concert given by the Chilean group Inti Illimani, the Greek anti-junta icon Maria Farantouri, and the Turkish exiled artist Zülfü Livaneli. ${ }^{137}$ Over the 1980 , Chilean artists continued to perform in the East and West against the odds of the Second Cold War. The appeal of Chile in the I980s was not, however, what it had been in the I970s. Christian Democrats and the Catholic Church took a leading role in the domestic opposition in Chile, whereas the Chilean left in exile was weakly organized, divided, and discredited by continuing relations with communist regimes in Eastern Europe. ${ }^{138}$ These relations would remain important throughout the late I980s and early I990s however. Even in the I980s, the programme Escucha Chile broadcast by Radio Moscow remained a key source of information for many local committees in Western European countries. ${ }^{139}$ In 1987, Clodomiro Almeyda was able to return clandestinely to Chile with the help of the German Democratic Republic. ${ }^{10}$ After the end of the Pinochet regime and as Chilean ambassador in Moscow, Almeyda, in turn, helped the deposed East German leader Erich Honecker to find refuge in Chile, where he was welcomed in 1993 and died some months later. ${ }^{\mathrm{I} I \mathrm{I}}$

I 35. Angell, "International Support", p. I 83. See also Archivo Digital de la Fundación Museo de la Memoria y los Derechos Humanos. Documents concerning the International Commission of Enquiry into the Crimes of the Military Junta in Chile, http://www.archivomuseodelamemoria. cl/uploads/1/0/104732/0000003 I0000I 2000162.pdf; last accessed 28 June 2017.

I36. El derecho de vivir en paz, I6 September 1983, Amsab-ISG, Ghent, AF.o05660.

137. Le Soir, 16 September 1983, p. 3.

I38. Committee for the Defence of Human and Trade Union Rights in Latin America, Brussels, I I October 1984, ICFTU, IISH, no. I 489.

I39. See for instance the role of Escuch a Chile in local activism in Belgium: Walter Lotens, Elcker$I k$, 45 jaar sociale actie (Tielt, 2015 ).

I40. Sebastian Koch, Zufluchtsort DDR? Chilenische Flüchtlinge und die Ausländerpolitik der SED (Paderborn, 2016), p. I I I.

I4 I. Mary Helen Spooner, The General's Slow Retreat: Chile after Pinochet (Berkeley, CA [etc.], 20II), p. 52; Thomas Kunze and Markus Rosenberger, “'Es lebe der Sozialismus'. Margot 
Many former exiles and new political leaders in Chile feared rather than welcomed the consequences of the collapse of communism in Eastern Europe in 1989-1991. They saw post-communist Europe as a potential competitor detracting Western support for the country's transition to democracy, and Europe's coming together as an exclusion of the Third World. ${ }^{\mathrm{I} 2}$ Conversely, after 1989 , neoliberal reformers and former dissidents in post-communist Europe turned to the model of Pinochet's Chile: they studied Pinochet's economic "miracle" as a roadmap of how to go from communism to free market capitalism. ${ }^{\mathrm{I} 3}$ Such alliances were at odds, however, with the post-1989 euphoria in the West, and went largely ignored. After the events of I989, amnesia allowed liberals, the left, and Eastern European dissidents turned into political leaders to cherish the narrative of one global anti-totalitarian struggle against fascism in Latin America and communism in the East. ${ }^{\mathrm{I}}{ }^{4}$

\section{CONCLUSIONS}

The rise of human rights campaigns on behalf of Chile and the support these campaigns received in Europe have often been represented and remembered as an expression of a post-war European identity that holds democracy and human rights as the central pillars of its self-understanding. ${ }^{145}$ It has been the story of Western Europe that starts to identify itself with democracy and human rights by counterpointing itself to both Eastern European communism and the plight of the Third World. ${ }^{146}$ This "democratic" Europe projected human rights internationally and became a model that supported and inspired opposition to dictatorships in Chile and many other countries in the Third World from the I970s onwards. From this perspective, the crushing of the Allende government in 1973 was a watershed moment: it signalled the failure of the "Third World" as a model for democracy and

Honecker als Symbolfigur in Chile, Nicaragua und Namibia", in Thomas Kunze and Thomas Vogel (eds), Ostalgie international. Erinnerungen an die DDR von Nicaragua bis Vietnam (Berlin, 2010), pp. 27-43.

I42. Micheline de Sève, "La chute du mur de Berlin et l'ébranlement de la gauche chilienne", Politique et Sociétés, 24:2-3 (2005), pp. 87-107, 95.

I43. Rupprecht, "Formula Pinochet".

I44. Patricio A. Guzmán Contreras and Alexis A. Sanhueza Rodríguez, "Chile, su comportamiento y visión hacia los cambios en Polonia (1988-199I)", Revista Sociedad y Cultura, I (2014), pp. I03-I 23, https://www.scribd.com/document/268062826/Relaciones-Internacionales-Chiley-Polonia-ı 988-ı99i; last accessed 28 April 2018.

I45. See for instance Patrick Pasture, Imagining European Unity Since I000 AD (Basingstoke and New York, 2015), pp. I9I-I93.

I46. Helle Porsdam, "Human Rights and European Identity since World War II: Vergangenheitsbewältigung through Law", in M. Spiering and M. Wintle (eds), European Identity and the Second World War (Basingstoke, 20I I), pp. 2 I-36, 24. 
socialism for the European left, and focused attention on "European" solutions and models - East-West détente, the end of authoritarianism in Southern Europe, and the struggle against communism in Eastern Europe. After the end of the Cold War, this narrative shifted into a selfcongratulatory mode: the end of the Pinochet regime and other authoritarian regimes in the Third World - such as apartheid in South Africa and what was dubbed the "red dictatorship" of the Sandinistas in Nicaragua were linked to the fall of communism in Eastern Europe. They were celebrated as one common victory of human rights: Samuel Huntington's theory of a "global democratization wave" that spiralled outward from Southern Europe to Latin America and other regions across the world, and eventually landed in Eastern Europe in the late I980s, fitted conveniently into these narratives. So-called transitologists were keen to "Europeanize" the transition in Chile: these accounts emphasized the role of Western European support on the one hand and the fall of Eastern European communism on the other in Chile's return to democracy and in turning the Chilean left from communists into democrats. ${ }^{147}$ Paradoxically, such narratives have been confirmed rather than challenged by new histories of human rights - which have seen the rise of human rights as a Cold War artefact that served an attempted integration of the Second and Third World into the West, and eventually contributed to the end of the Cold War. ${ }^{\text {I48 }}$

Such storylines are riddled with blind spots. The history of the support Pinochet received in Western Europe has, for instance, remained a virtually uncharted territory of academic research, and largely remains to be written. ${ }^{49}$ Such narrations also conceal how, in the I970s and I980s, human rights campaigns on behalf of Chile did not so much juxtapose Europe with the plight of Third World, but rather stressed analogies and connections. This becomes obvious in the potent connections and intersections that emerged between campaigns on behalf of Chile and those on behalf of causes within Europe. In the mid-I970s, campaigns over Chile were inspired by the belief that the plight of Third World countries such as Chile paralleled the economic and political decline of Europe, and they projected the vision that East-West détente was crucial to liberate both Europe and its former colonies from the burden of the Cold War. Campaigns constructed one common struggle against fascism in Europe and Latin America - as exemplified by the connection that emerged between campaigns over Chile

I47. See for instance Alan Angell, "International Support for the Chilean Opposition, 19731989: Political Parties and the Role of Exiles", in Laurence Whitehead (ed.), The International Dimensions of Democratization: Europe and the Americas (Oxford, 2001), pp. 175-200.

148. Samuel Moyn, The Last Utopia: Human Rights in History (Cambridge, 2010).

149. See for instance Fernando Camacho Padilla, "The Swedish-Chilean Society: Fascist Solidarity with Pinochet's Chile in Sweden", in Hansen et al., Making Sense of the Americas, Pp. I3 I-I 50 . 
and those against Southern Europe's authoritarian regimes. Against the backdrop of the economic crisis after I973, campaigns portrayed Western Europe and Chile as common victims of neo-colonialism and imperialism most notably by the US. In the mid-r 970 , the end of fascism and colonialism in Portugal, followed by the collapse of dictatorships in Greece and Spain, as well as the simultaneous consolidation of East-West détente in the Helsinki Agreements, appeared to confirm Europe's role in bringing change in the Third World. Communist movements, Social Democrats, Chilean exiles, but also many national liberation movements in the Third World used the nexus between the end of fascism and détente in Europe to carve out a global role for Europe: they cultivated the belief in its potential to change the stalemate of the Cold War, which was held responsible for the stamina of fascism and imperialism in the Third World. They aimed to give a new future in Europe to principles such as anti-fascism, non-alignment, democracy, and socialism, which had failed in Chile and other Third World countries. In 1977, Romesh Chandra, the Indian president of the World Peace Council, captured this vision during an international conference on anti-apartheid in Lisbon, which declared its solidarity with the Chilean opposition and was attended by Chilean delegations: he drew a line under Europe's colonial past and spoke about a "new Europe [...] from which the voice of peace rings out to proclaim solidarity with the struggle of all peoples of the world. This is the Europe which, two years ago, signed the Final Act of the Helsinki Conference for Security and Cooperation in Europe". ${ }^{50}$ Such optimism faded, however, in the I980s with the deterioration of détente. Eastern European dissidents and their anti-communist supporters, for their part, used campaigns on behalf of Chile to draw attention to the existence of another "Third World" within the borders of Europe, namely the Eastern bloc suffering from Soviet imperialism. ${ }^{\text {I I I }}$

Rather than signalling a breakthrough of "global civil society" or simply presenting Europe as a model for the return of democracy and human rights, campaigns used the Chilean cause to make sense of Europe's past and future and to build a common cause between Europe and the "Third World". These European reconfigurations emerged from a broad range of actors and ideas that have remained marginal in mainstream memories and histories of campaigns on behalf of Chile. Actors coming from what have often been seen as "peripheries" in the history of human rights activism, such as the Chilean opposition, Southern European political leaders, Eastern European dissidents, and communist movements, invested human rights

I 50. Portuguese National Committee against Apartheid, Racism and Colonialism in Southern Africa, World Conference against Apartheid, Racism and Colonialism in Southern Africa, Lisbon June I6-19 1977 (Lisbon, I977), p. 78.

I I. James Mark and Quinn Slobodian, "Eastern Europe”, in Martin Thomas and Andrew Thompson (eds), The Oxford Handbook of the Ends of Empire (Oxford, 2018). 
campaigns on behalf of Chile with pan-European themes and made them an avenue to foster bonds of solidarity within Europe. The variety of ideas that underpinned these shifting reconfigurations during the I970s and I980s ranging from anti-fascism and socialism to peace and anti-communism reveal how human rights were not a single packet, but were deeply contested.

\section{TRANSLATED ABSTRACTS FRENCH - GERMAN - SPANISH}

Kim Christiaens. Reconfigurations européennes de l'activisme transnational. Solidarité et campagnes pour les droits de l'homme au nom du Chili an cours des années 1970 et 1980.

La chute de Salvadore Allende, président socialiste du Chili démocratiquement élu et les violations des droits de l'homme sous la junte militaire d'Augusto Pinochet ont engendré une campagne en faveur des droits de l'homme qui est l'une des plus iconiques et des plus intenses de la Guerre froide. Les chercheurs en matière de droits de l'homme avancent que ce mouvement au nom du Chili marque la «percée » des droits de l'homme en tant que lingua franca de l'activisme transnational. Ils soulignent les dimensions globales de ces campagnes qui ont inspiré des mouvements mobilisateurs au nom d'autres problèmes dans le Tiers monde. Ces récits ne sont cependant pas corroborés par une recherche sur les campagnes telle qu'elle existe en Europe. Jusqu'à présent, les historiens se sont concentrés sur l'impact de la crise chilienne dans certains pays spécifiques ou sur des organisations particulières, ainsi que sur les manières dont l'activisme en faveur des droits de l'homme est coloré par des contextes locaux et nationaux. Cet article vise à réorienter la portée de ce débat en établissant des relations avec d'autres causes et campagnes transnationales et en jetant des ponts à partir de celles-ci, et en analysant les manières dont les campagnes au nom du Chili deviennent étroitement liées à des campagnes sur des questions intra-européennes au cours des années 1970 et 1980 . L'article examine les relations jusqu'à présent peu étudiées entre les campagnes sur le Chili et les mouvements simultanément naissants au nom de la détente Est-Ouest, la résistance contre les régimes autoritaires en Europe du Sud et la situation désespérée des dissidents en Europe de l'Est. Il soutient que les campagnes au nom du Chili se reconfigurent autour de thèmes européens, créent des liens de solidarité au sein d'une Europe divisée et s'inspirent d'analogies plutôt que d'une juxtaposition entre l'Europe et le Tiers monde.

Traduction: Christine Plard

Kim Christiaens. Europäische Umgestaltungen des transnationalen Aktivismus. Solidaritäts- und Menschenrechtskampagnen für Chile während der I97oer und I980er Jabre.

Der Sturz des demokratisch gewählten, sozialistischen Präsidenten Salvador Allende in Chile und die unter der Militärjunta von Augusto Pinochet begangenen Menschenrechtsverletzungen führten $\mathrm{zu}$ einer der symbolträchtigsten und 
nachhaltigsten Menschenrechtskampagnen des Kalten Kriegs. Menschenrechtsforscher haben die These vertreten, diese Bewegung für Chile markiere den »Durchbruch « der Menschenrechte als Lingua franca des transnationalen Aktivismus. Darüber hinaus haben sie die globale Reichweite der entsprechenden Kampagnen betont. Diese habe Bewegungen, die zu anderen Fragen der Dritten Welt mobilisierten, als Inspiration gedient. Solche Narrative sind allerdings nicht mit Befunden zu europäischen Kampagnen untermauert worden. Historiker haben sich bislang auf die Auswirkungen der chilenischen Krise in einzelnen Ländern beziehungsweise auf bestimmte Organisationen konzentriert, sowie auf die lokalen und nationalen Prägungen des Menschenrechtsaktivismus. Dieser Artikel versucht, die Debatte dadurch zu erweitern, dass er Verbindungen zu und Überschneidungen mit anderen transnationalen Anliegen und Kampagnen aufzeigt. Dabei wird analysiert, wie die Kampagnen für Chile in den I970er und I980er Jahren eine enge Verbindung $\mathrm{zu}$ anderen, mit innereuropäischen Fragen befassten Kampagnen entwickelt haben. Es wird den bislang wenig erforschten Zusammenhängen nachgegangen, die zwischen den Kampagnen für Chile und den zeitgleich entstehenden Bewegung für eine Ost-West-Entspannungspolitik bestanden, aber auch zwischen der Chile-Solidarität und dem Widerstand gegen autoritäre Regime in Südeuropa oder dem Einsatz für osteuropäische Dissidenten. Es wird die These vertreten, dass die Kampagnen für Chile um europäische Themen herum entwickelt wurden, solidarische Bande innerhalb eines geteilten Europa schufen und eher auf Analogien zwischen Europa und der Dritten Welt als auf deren Gegenüberstellung, beruhten.

Übersetzung: Max Henninger

Kim Christiaens. Reconfiguraciones europeas del activismo transnacional. Solidaridad y campañas por los derechos humanos en Chile durante las décadas de 1970 y 1980.

El derrocamiento del Presidente socialista elegido de forma democrática Salvador Allende en Chile y las violaciones de los derechos humanos bajo la junta militar de Augusto Pinochet generó una de las campañas en defensa de los derechos humanos más icónicas y prolongadas del periodo de la Guerra Fría. Los/as investigadores/as que se han dedicado a los derechos humanos han señalado que este movimiento cuya atención se centraba en Chile significó el "éxito" de los derechos humanos como lingua franca del activismo transnacional. De igual forma han puesto énfasis en las dimensiones globales de estas campañas que sirvieron de inspiración a movimientos que se movilizaban centrados en diferentes aspectos en relación con el Tercer Mundo. Sin embargo, estas narrativas no han sido corroboradas mediante la investigación sobre las campañas que se promovieron en Europa. Los/as historiadores/as hasta el momento han centrado su interés en el impacto que tuvo la crisis chilena en países específicos o en determinadas organizaciones, y en las formas en que el activismo en favor de los derechos humanos estuvo influenciado por los contextos locales y nacionales. Este artículo pretende proponer un cambio en el alcance de la discusión estableciendo relaciones y conexiones con otras causas y campañas transnacionales analizando las formas en que las campañas centradas en Chile llegaron a estar de forma muy estrecha con campañas centradas en cuestiones intraeuropeas a lo largo de las décadas de 1970 y 1980 . Se exploran también las conexiones hasta este momento 
poco estudiadas entre las campañas sobre Chile y, de forma simultánea, los nacientes movimientos focalizados en la distensión Este-Oeste, la resistencia contra los regímenes autoritarios en el sur de Europa y la complicada situación de los/las disidentes en Europa Oriental. El texto plantea que las campañas focalizadas en Chile se reconfiguraron en función de las preocupaciones europeas, crearon vínculos de solidaridad en una Europa dividida y se fundaron en analogías más que en una yuxtaposición entre Europa y el Tercer Mundo.

Traducción: Vicent Sanz Rozalén 